\title{
The microbiome of the upper respiratory tract in health and disease
}

\author{
Christina Kumpitsch ${ }^{1}$, Kaisa Koskinen ${ }^{1}$, Veronika Schöpf ${ }^{2,3,4}$ and Christine Moissl-Eichinger ${ }^{1,3^{*}}$
}

\begin{abstract}
The human upper respiratory tract (URT) offers a variety of niches for microbial colonization. Local microbial communities are shaped by the different characteristics of the specific location within the URT, but also by the interaction with both external and intrinsic factors, such as ageing, diseases, immune responses, olfactory function, and lifestyle habits such as smoking. We summarize here the current knowledge about the URT microbiome in health and disease, discuss methodological issues, and consider the potential of the nasal microbiome to be used for medical diagnostics and as a target for therapy.
\end{abstract}

Keywords: Microbiome, Upper respiratory tract, URT, Human microbiome, Nasal microbiome, Upper respiratory tract diseases

\section{Introduction}

The human microbiome is a complex community of microorganisms, living in a symbiotic relationship in human microhabitats. Due to microbial niche specificity, microbial composition and function vary according to the different human body sites, such as the gastrointestinal tract, skin, and airways $[1,2]$.

Since a healthy adult breathes more than $7000 \mathrm{l}$ of air a day, the upper respiratory tract (URT) is constantly bathed in airflow from the external environment. Along with the air, $10^{4}-10^{6}$ bacterial cells per cubic meter of air are inhaled per day. Besides these biological particulates, the URT is exposed to atmospheric physical and chemical parameters, including varying humidity, oxygen, immunological factors, or nutrients. Along with the anatomy, these factors shape specific microenvironments in the URT such as the nasal cavity, sinuses, nasopharynx, and oropharynx [3-5]. As a consequence, specific microenvironments in the URT harbor different microbial communities composed of variable proportions of resident and transient microorganisms [6].

Like other human body sites, the upper respiratory tract is colonized by a variety of different microbial species directly after birth. It has been shown that the initial

\footnotetext{
* Correspondence: christine.moissl-eichinger@medunigraz.at

${ }^{1}$ Diagnostic and Research Institute of Hygiene, Microbiology and

Environmental Medicine, Medical University of Graz, Neue Stiftingtalstraße 6, 8010 Graz, Austria

${ }^{3}$ BioTechMed-Graz, Mozartgasse 12/II, 8010 Graz, Austria

Full list of author information is available at the end of the article
}

colonization depends on delivery mode (vaginal delivery or caesarean section), and the most drastic changes occur during the first year of life, probably driven by the maturation of the immune system [7]. Later on, this first microbial community transforms into the adult URT microbiome, becoming less dense and more diverse. In the elderly, the distinct microbiomes of specific microenvironments become more similar $[8,9]$.

Many studies report that the nasal microbiome of healthy humans is primarily composed of the phyla Actinobacteria, Bacteroidetes, Firmicutes, and Proteobacteria with representatives of genera Bifidobacterium, Corynebacterium, Staphylococcus, Streptococcus, Dolosigranulum, and Moraxella predominating [9-12]. However, most research focuses on the bacteria in the human nasal cavity, while other components of the microbiome, such as viruses, archaea, and fungi, are seldom specifically addressed and thus likely overlooked [13].

Human health has been described as the outcome of the complex interaction between the microbiome and its human host [14]. Functional or compositional perturbations of the microbiome can occur at different body sites and this dysbiosis has been linked with various diseases; for example, inflammatory bowel disease and metabolic disorders have been linked to dysbiosis in the microbiome of the gastrointestinal tract and URT infections (URTI, such as chronic rhinosinusitis [CRS]) with dysbiosis in the URT [15-18]. These dysbioses are often characterized by a loss of beneficial, commensal bacteria,

(c) The Author(s). 2019 Open Access This article is distributed under the terms of the Creative Commons Attribution 4.0 International License (http://creativecommons.org/licenses/by/4.0/), which permits unrestricted use, distribution, and 
which protect against overgrowth of opportunistic pathogenic bacteria $[6,19,20]$.

Currently, several different therapies are suggested for the treatment of inflammatory URTIs [21-24]. Antibiotics as well as intranasal corticosteroids are used, combining antimicrobial and anti-inflammatory properties $[21,24]$. These treatments cause a loss of microbial diversity, potentially leading to an increase of Gramnegative bacteria in the nose [25-27].

In the case of chronic rhinosinusitis, sinus surgery (aiming at improving drainage of the mucus), combined with different antibiotics is the most common treatment [22]. Although this type of therapy is highly invasive, its outcomes are usually satisfactory [28]. However, airway diseases might also be prevented and treated with less aggressive therapies such as saline rinses, cleaning the nasal mucosa from inflammatory mediators and other pollutants [23].

Comparative URT microbiome research faces various methodological problems, including choice of sampling techniques (e.g., swabs, nasal rinses, and dry filter papers) and sampling sites. In most cases anterior nares, middle meatus, and nasopharynx are the preferred sites for sampling [9, 11, 12, 29-31], as other areas are not easily accessible. This often results in a discrepancy of research question and study protocol, as, e.g., the middle meatus is sampled instead of the sinuses when chronic rhinosinusitis is studied [29]. However, microbiome dysbiosis often extends to locations beyond the sites of the studied disease, so that significant alterations in the microbial community structure in adjacent locations can be observed as well $[6,32]$. Nevertheless, in order to prove or reject a research hypothesis, the sampling sites for microbiome analyses need to be chosen wisely [6].

The aim of this review is to summarize the current information about the microbiome in the upper respiratory tract; discuss methodological issues such as sampling methods and sites; present the link between URT microbiome composition, immune system, and certain diseases; have a look at the influence of common therapies on the URT microbiome; and identify the current gaps in our knowledge.

Details of cited studies, including sampling, sample processing protocol, studied population and sites, and results are summarized in Additional file 1.

\section{Landscape of the upper respiratory tract}

The upper respiratory tract (URT) comprises the anterior nares, nasal cavity, sinuses, nasopharynx, Eustachian tube, middle ear cavity, oral cavity, oropharynx, and larynx. The nasal cavity is partitioned into the inferior, middle, and superior meatus by three nasal turbinates [3, 33] (Fig. 1a). In this review we focus on the microbiomes of anterior nares, nasal cavity, sinuses, and nasopharynx and their importance in human health.

Many important physiological functions are provided by the URT such as filtering, warming, and humidifying of inhaled air [3, 34]. As the nasal cavity is in constant contact with the external environment, it acts as a physical transition forming an interface between the external environment and the lower respiratory and gastrointestinal tract $[3,33]$. Other functions are olfactory sensing and important immunological tasks, including immediate pathogen detection such as sensing of bacterial lactones by taste receptors [32, 35-38].

The nasal cavity is lined by different types of epithelium, providing different micro-niches (Fig. 1a): the anterior naris starts with non-keratinized skin-like epithelium (1), changing into stratified squamous epithelial cells without microvilli (2), followed by transitional epithelium with short microvilli (3), before transition into the middle meatus with its pseudostratified columnar epithelium (4 and 5, middle meatus) [32, 33, 35]. The most common sampling sites for nasal microbiome analyses are the anterior nares (AN), the middle meatus (MM), and the nasopharynx [9, 12, 29, 31] (Fig. 1a).

The surfaces in the anterior nares and nasal vestibule are relatively dry compared to other URT areas. These parts experience the greatest exposure to the external environment and contain sebaceous glands (see below) and vibrissae (hair). These hairs trap large particles (> $3 \mu \mathrm{m})$ from inhaled air, whereas small particulate matter $(0.5-3 \mu \mathrm{m}$, including microorganisms) is captured by a flowing mucus blanket covering the entire nasal cavity [32, 33, 35, 39].

The middle meatus is adjacent to the nasal vestibule. As it receives drainage from the anterior ethmoids, maxillary, and frontal sinuses, this area is of interest for many microbiome studies [32]. The nasopharynx is characterized by many crypts and folds, and its wall is dominated by keratinized and non-keratinized stratified squamous epithelium and pseudostratified ciliated epithelia [40].

Maxillary, ethmoid, sphenoid, and frontal sinuses are air-filled, paired cavities within the facial skeleton, which are important for humidification and warming of the inhaled air (Fig. 1b). They are coated with ciliated columnar epithelium, which produces mucus that is transported into the nasal cavity [41]. These drainages create local micro-niches with specific microbial populations within the nasal cavity [42] (Fig. 2). Another interesting niche for microbiome studies is the olfactory area, as recent studies indicated a potential correlation of olfactory function with the taxonomic composition of the local nasal microbiome [43]. The olfactory area is located at the ceiling of the nasal cavity [33]. 

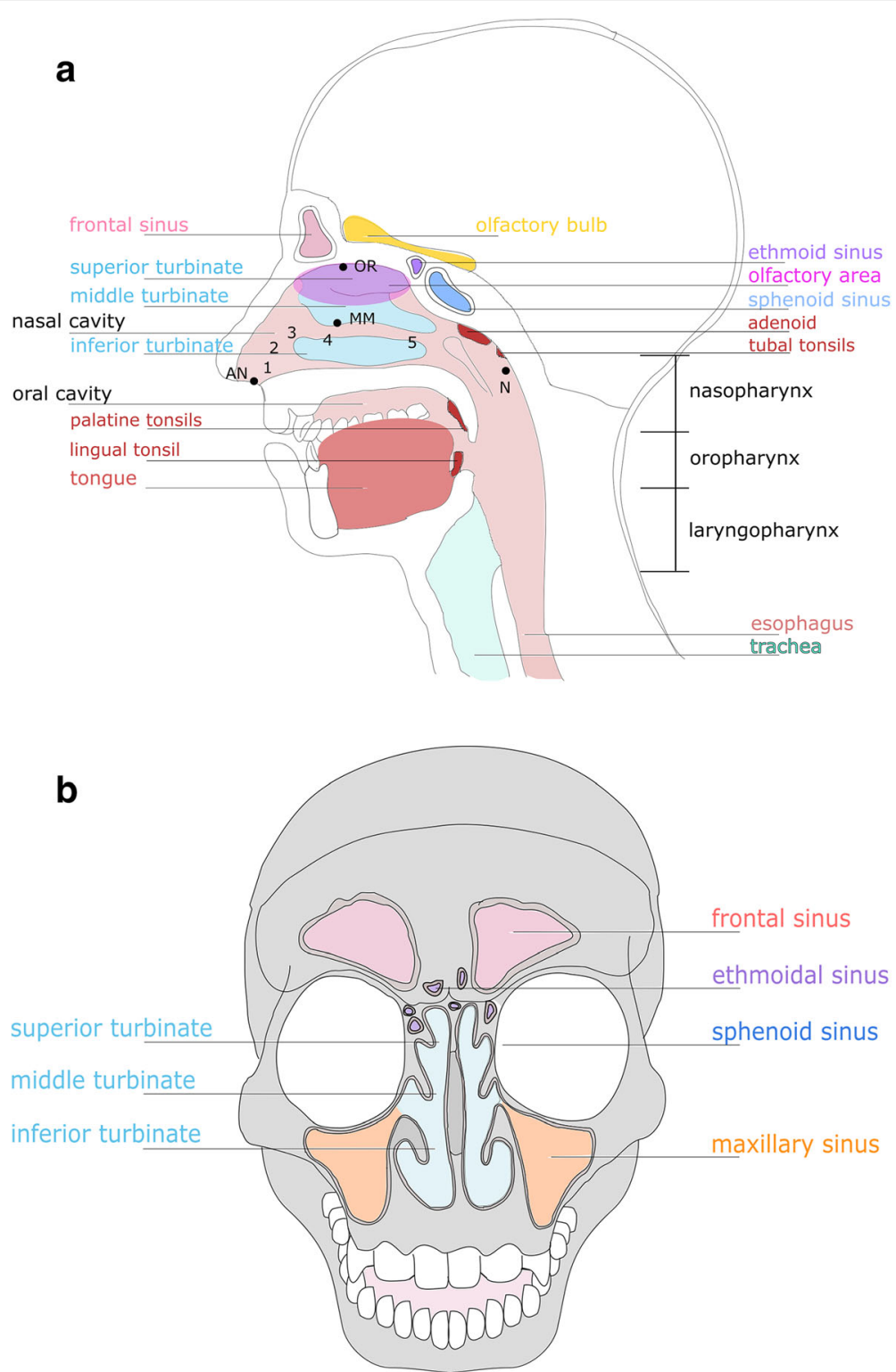

Fig. 1 The upper respiratory tract (a) and its paranasal sinuses (b). a URT with different, typical microbiome sampling sites (AN anterior naris, MM middle meatus, OR olfactory area and nasopharynx) and nasal lining, starting with 1 non-keratinized skin-like epithelium in the nostrils followed by different epithelial types, 2 squamous epithelium without microvilli, 3 transitional epithelium with ciliated cells, 4 pseudostratified columnar epithelium with ciliated cells, 5 pseudostratified columnar epithelium with many ciliated cells. b Sinuses of the nasal cavity

\section{Upper respiratory (immune) defense system}

The respiratory tract has recourse to a variety of mechanisms, including components of the innate and adaptive immune system, to protect against possibly harmful, inhaled microorganisms while chronically present commensal microbes of the URT microbiome are tolerated due to hyporesponsiveness of the host's immune system [44].

\section{The mucus layer}

Glands, goblet cells, and ciliated cells secrete a hydrated mucus layer which contains lipids, glycoproteins, and glycoconjugates. This layer not only helps to humidify inhaled air but also traps microbes and microparticles from the environment on entering the URT $[33,45]$. This "contaminated" mucus is then directed by ciliated epithelial cells (located in the upper respiratory tract) from the nasal cavity towards the esophagus $[33,45]$. This whole process of purging is also known as mucociliary clearance $[46,47]$. Additional defense is derived from antimicrobial compounds which are present in the mucus and immediate initiation of immune priming [32, 48]. Interestingly, commensal bacteria with immunomodulatory properties are 


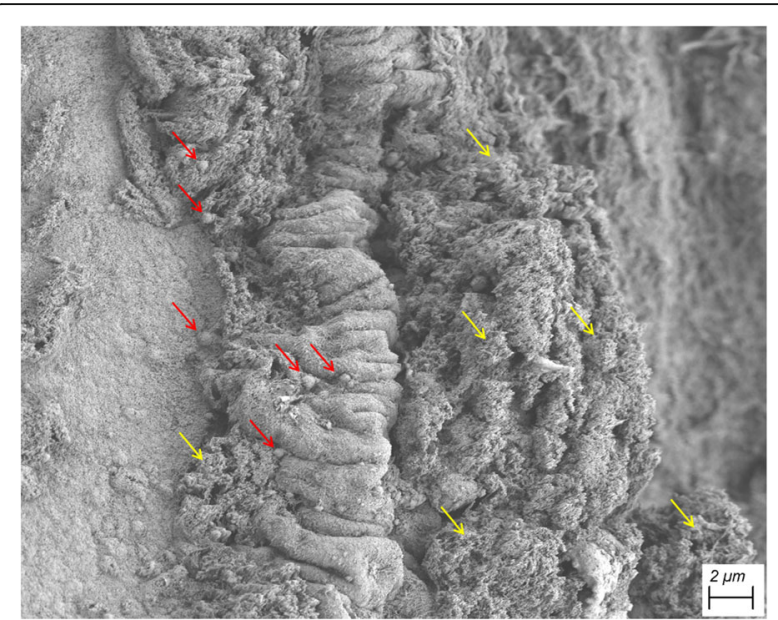

Fig. 2 Scanning electron micrograph of nasal mucus of a healthy subject exhibiting various structures (red arrows point at bacterial-like structures, yellow arrows show areas with nasal phlegm)

capable of priming a host's immune responses to assure efficient and rapid defense against pathogens $[49,50]$.

\section{Antimicrobial peptides and reactive oxygen species}

The respiratory surface epithelium secretes a variety of antimicrobial components. These include antimicrobial peptides such as lysozyme, lactoferrin or defensins, and reactive oxygen species (ROS) such as hydrogen peroxide and nitric oxide (NO) [51-55]. Besides its antimicrobial activity (it diffuses into the microbial cell and destroys intracellular components), nitric oxide also directly increases mucociliary clearance and speeds up the frequency of ciliary beating by protein kinase $\mathrm{G}$ and guanylyl cyclase activation $[38,56-58]$.

\section{Nasopharyngeal-associated lymphoid tissue}

Nasopharyngeal tonsils (adenoids), the paired tubal tonsils, the paired palatine tonsils, and the lingual tonsil are part of the lymphoid tissue in the nasopharynx and serve as major sites for microbial recognition and defense [59, 60]. Nasopharyngeal-associated lymphoid tissue (NALT) harbors a large variety and number of immune cells, including dendritic cells, macrophages, and lymphocytes [61] (Fig. 1a). Fifty percent of these lymphocytes are immunoglobulin-producing B-lymphocytes [62-64]. Like the small intestine, the lymphoid tissues contain M cells, which transport microorganisms via trans-epithelial transport from the apical surface to the basolateral site where immune cells are already waiting [65]. NALTassociated cells (e.g., sinonasal solitary chemosensory cells) excrete chemokines and cytokines, which activate downstream immune cascades [66-68].

\section{Olfaction- and taste-triggered immune response}

Foreign substances in the URT can also be detected by two other systems, the extended olfactory and the trigeminal chemesthetic system. The former includes the olfactory epithelium and vomeronasal organ [69]. Stimulation thereof by different signals (food odors, sexual and social signals, as well as bacterial infection products like formyl peptides) was shown to cause behavioral responses in mouse experiments [70,71].

The trigeminal chemesthetic system (including solitary chemosensory cells (SCCs)) [69] induces protective trigeminal nerve-mediated airway reflexes (coughing, sneezing, or decrease in breathing rate) and local inflammatory responses [72-74]. These SCCs make up to $1 \%$ of all cells in the ciliated epithelium of the sinonasal cavity $[66,75]$ and express two types of taste receptors, bitter and sweet [76, 77]. These receptors belong to the group of G-protein-coupled receptors (GPCRs) [78, 79].

With bitter receptors (e.g., T2R family), the sensory system of the SCCs is able to detect the presence of bacteria on nasal epithelial surfaces directly via bitter molecules that are released by pathogens $[56,73,76]$ and may initiate immune responses (e.g., inflammation) even before bacteria achieve a pathogenic load and are able to form biofilms [38, 56, 80]. An example of a bitter, microbial-derived molecule is acyl-homoserine lactone (AHL). AHL is an important bacterial quorum-sensing molecule [36-38] that stimulates the bitter receptor T2R38 and leads to calcium-dependent nitric oxide (NO) production [56].

It should be noted that bitter and sweet signals affect innate immunity oppositely. Sugars, such as sucrose and glucose, inhibit bitter-induced calcium release. As a consequence, downstream, calcium-driven initiation of the innate immune system at the tissue level (such as release of antimicrobials from ciliated cells) is impaired [76, 80].

In patients suffering from prediabetes and diabetes, increased levels of glucose have been found in nasal secretions [81]. In addition, chronic rhinosinusitis patients reported higher intensity of the sweet tastes (sucrose) whereas their ability to taste bitter compounds was reduced compared to healthy controls, both leading to decreases in pathogen detection and defense, e.g., by reduced ciliary beating $[38,82,83]$. Furthermore, it is hypothesized that glucose levels in the airways rapidly deplete during a bacterial infection due to the bacterial load [82, 84].

\section{The upper respiratory tract microbiome changes with age and life-style}

As we have seen, the landscape of the upper respiratory tract, with its different epithelial linings and conditions, provides numerous different (micro-)niches for microbial communities. Whereas the anterior naris (the passage between the skin and the nasal cavity) harbors commensals and opportunistic pathogens like Staphylococcus aureus, S. epidermidis, Propionibacterium (now: 
Cutibacterium) acnes, Dolosigranulum pigrum, Finegoldia magna, Corynebacterium spp., Moraxella spp., Peptoniphilus spp., and Anaerococcus spp. [85, 86], the microbial community structures in other locations in the nasal cavity and down the nasopharynx are distinct, especially in adults $[9,10]$ (see also Additional File 1). Even though the URT microbiome is largely individual, changes in inter-individual bacterial community profiles over different seasons (winter vs summer) and ages can still be observed [1, 86-89].

\section{The upper respiratory tract microbiome of infants}

Moraxella, Staphylococcus, Streptococcus, Haemophilus, Dolosigranulum, and Corynebacterium are the six most common genera, of which one or two usually dominate the nares and nasopharyngeal microbiome of infants [11, 90, 91]. Right after birth, the initial nasopharyngeal bacterial assemblage takes place, and the infant's nasopharyngeal microbiome resembles the maternal vaginal or skin microbiome [3, 92] (Fig. 3).

At 1.5 months of life this initial microbiome composition is maintained by breast feeding, which supports stable Dolosigranulum/Corynebacterium profiles. This is different to formula-fed infants, who show increased $S$. aureus signatures. The microbial profile of breast-fed infants seems to have a protective effect against respiratory infections [3, 93] (Fig. 3).
The nares and nasopharynx are dominated by Staphylococcus, Moraxella, Streptococcus, Corynebacterium, and/or Dolosigranulum signatures in 1.5-month-old infants [92]. Children with Moraxella spp.-dominated profiles were less likely to suffer from URTI, with the exception of Moraxella catarrhalis, which is found to be associated-together with $H$. influenza and S. pneumoniae-with wheezing in one-month-old infants. Nasopharyngeal Streptococcus was found to serve as a strong predictor for asthma in approximately 2-month-old children [27, 47, 92, 94]. After 1.5 months, Haemophilus-dominated clusters of co-occurrent microorganisms emerged, whereas Staphylococcus-dominated profiles disappeared and Corynebacterium/Dolosigranulum patterns were replaced by Moraxella/Dolosigranulum-dominated clusters in the infants' URT [92] (Fig. 3).

All in all, observations of children in their first 2 years of life show that Dolosigranulum and Moraxella combined with Corynebacterium form a more stable microbiome compared to Streptococcus and Haemophilus-dominant profiles $[26,92]$. The latter profiles $(H$. influenza and $S$. pneumoniae) were associated with respiratory viruses and an elevated risk of bronchiolitis in early life [30, 92, 9597] (Additional file 1).

\section{The upper respiratory tract microbiome of adults}

The URT microbiome of adults differs from that of infants, although the niche characteristics appear quite

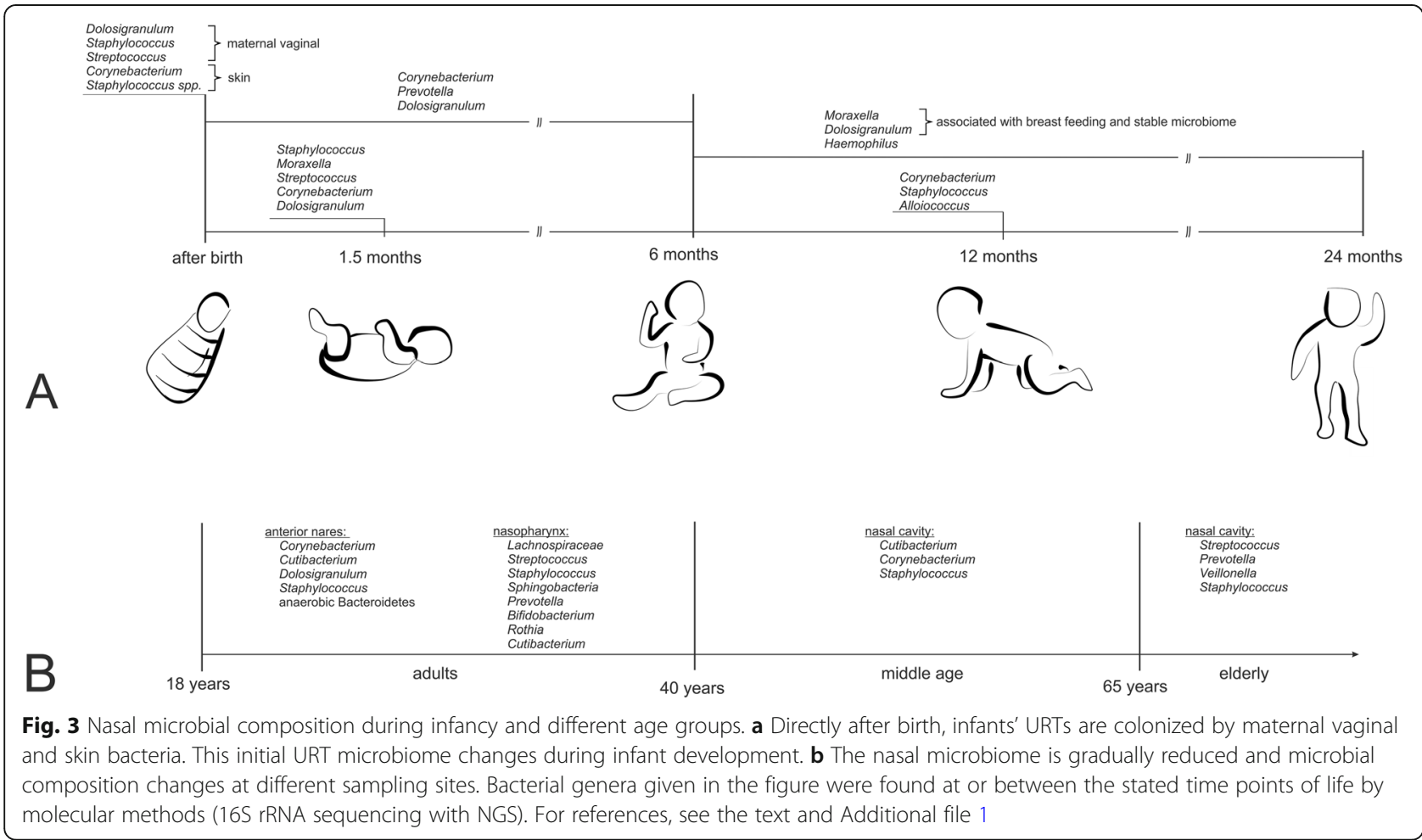


similar. In comparison, children's nasal microbiomes are more dense (higher bacterial load) but less diverse [3, 8, $12,47,98]$. The anterior nares of adults mainly harbor Actinobacteria, Firmicutes, and, in lower abundance, anaerobic Bacteroidetes [3, 31, 43, 98-100] (Fig. 3; Additional File 1).

Comparison of different nasal cavity sample sites showed that middle meatus (MM) and sphenoethmoidal recess (SR) are nearly identical with respect to microbial community composition, whereas anterior nares show a significantly reduced diversity of the microbial community. In addition, the anterior nares harbor a greater proportion of Firmicutes and Actinobacteria and less Proteobacteria compared to MM and SR [32].

The primary function of the nasal mucosa, namely the clearance of inhaled air, may explain the increased diversity of nasal mucosal samples [32]. At the phylum level, the adult nasopharynx microbiome resembles the microbiome of adult anterior nares, but the identified lower taxa are rather specific at the different locations [12] (Additional file 1).

\section{The upper respiratory tract microbiome of the elderly}

The microbial communities of the anterior nares of adults (18-40 years) differ significantly from that of other URT sampling sites (nasopharynx, tongue, buccal mucosa, oropharynx), but these distinctive variations gradually reduce during ageing. The alterations in nasal microbiota communities start in middle-aged adults ( $40-65$ years), whose nasal microbial communities are dominated by signatures of Cutibacterium, Corynebacterium, and Staphylococcus, whereas the nasal community of the elderly ( $>65$ years) shifts towards a more oropharyngeal population (Fig. 3) $[9,47]$. These observed changes in bacterial community composition are probably a consequence of immunesenescence during the process of aging, which leads to an increase of pro-inflammatory markers and decreased ability of immune stress handling, leading to the opening of new environmental niches after the loss of species richness $[9,101]$ (Additional file 1 ).

\section{Smoking influences the nasal microbiome}

Cigarette smoke exposure, whether active or passive, is associated with an elevated risk of not only cancer, periodontitis, and cardiovascular disease, but also chronic respiratory diseases (e.g., chronic obstructive pulmonary disease (COPD), asthma) and acute respiratory infections $[47,102]$.

Cigarette smoke has immediate contact with nasal surfaces, and thus directly impacts the microbiome by oxygen deprivation, antimicrobial activity, or other mechanisms $[103,104]$.

The toxic substances disrupt effective muco-ciliary clearance in the lower and upper respiratory tracts, impairing the immune responses against pathogens [105-109].

Cigarette smoke also enhances bacterial attachment to airway epithelial cells, for example, by inducing bacterial fimbrial protein FimA production, which promotes the formation of robust, reversible biofilms. This biofilm formation might support recalcitrant persistence of bacteria in the nasal cavity $[87,110-112]$.

Other studies suggested a direct alteration of bacterial infection and carriage pathways, as it has already been shown that $S$. aureus invasion and biofilm formation are elevated after cigarette exposure [47, 113, 114]. A similar effect was observed for pneumococcal biofilms [115, 116] (Additional file 1).

Several studies have shown that cigarette smoking depletes normal commensal airway microbiota and enriches potential pathogens ( $H$. influenzae, M. catarrhalis, Campylobacter spp., Streptococcus pneumoniae, and Streptococcus pyogenes) [47, 87, 117]. In general, URT communities of smokers were found to be more diverse but less robust in composition over time compared to non-smokers [87] (Table 1; Additional file 1).

The likelihood of carrying Gram-positive anaerobic lineages (Eggerthella, Erysipelotrichaceae I.S., Dorea, Anaerovorax, and Eubacterium spp.) is increased in the nasopharynx of smokers, including pathogens associated with URT infections and endocarditis (e.g., Abiotrophia spp.) [87] (Table 1; Additional file 1). In contrast, the upper respiratory tract of non-smokers harbors particularly Peptostreptococcus spp., $\alpha$-haemolytic streptococci, and Prevotella spp., which seem to correlate negatively with pathogen presence $[47,117]$.

Interestingly, after 1 year (12 to 15 months) without smoking, the microbiome composition seems to recover and resembles microbial patterns of never-smokers, accompanied by a decrease of the proportion of opportunistic pathogens $[87,111,120]$ (Table 1).

Smoking is not only harmful for adults, but also for infants when they are exposed to passive smoking. In general, $S$. pneumoniae was found to be elevated in infants with smoking parents [118]. Two-year-old children of smoking parents also have an increased risk of suffering from otitis media, meningococcal meningitis, and lower respiratory tract infections [111, 121, 122] (Additional file 1).

Notably, cigarettes themselves could be the source of these opportunistic pathogens. Sapkota et al. studied the bacterial metagenomes of commercially available cigarettes and discovered signatures of, e.g., Acinetobacter, Burkholderia, Clostridium, Klebsiella, Pseudomonas aeruginosa, and Serratia [119] (Table 1; Additional file 1).

\section{Microbial competition in the URT}

Most microbes associated with the human host interact positively with the host and each other. This collaboration 
Table 1 Summary of significant URT microbiome changes due to active and passive cigarette smoking

\begin{tabular}{|c|c|c|c|c|c|c|}
\hline Study & Population & Sample site & Actinobacteria & Bacteroidetes & Firmicutes & Proteobacteria \\
\hline $\begin{array}{l}\text { Charlson et al. } 2010 \\
\text { [87] }\end{array}$ & Adult & Nasopharynx & $\begin{array}{l}\downarrow \text { Actinomycetaceae } \\
\downarrow \text { Corynebacteriaceae } \\
\downarrow \text { Coriobacteriaceae } \\
\uparrow \text { Eggerthella }\end{array}$ & $\begin{array}{l}\downarrow \text { Flexibacteriaceae } \\
\downarrow \text { Flavobacteriaceae } \\
\uparrow \text { Porphyromonadaceae }\end{array}$ & 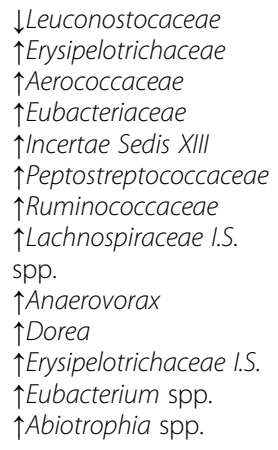 & $\begin{array}{l}\downarrow \text { Rhodocyclaceae } \\
\downarrow \text { Rhodobacteraceae } \\
\downarrow \text { Enterobacteriaceae } \\
\downarrow \text { Alcaligenaceae } \\
\downarrow \text { Methylophilacea } \\
\downarrow \text { Shigella spp. } \\
\uparrow \text { Pasteurellaceae } \\
\uparrow \text { Haemophilus spp. }\end{array}$ \\
\hline $\begin{array}{l}\text { Brook and Gober } 2005 \\
{[117]}\end{array}$ & Adult & Nasopharynx & & & $\begin{array}{l}\uparrow S t r e p t o c o c c u s \\
\text { pneumoniae } \\
\uparrow S t r e p t o c o c c u s \\
\text { pyogenes }\end{array}$ & $\begin{array}{l}\uparrow H . \text { influenzae } \\
\uparrow M \text {. catarrhalis }\end{array}$ \\
\hline $\begin{array}{l}\text { Greenberg et al. } 2006 \\
\text { [118] }\end{array}$ & Infants & Nasopharynx & & & $\begin{array}{l}\uparrow \text { Streptococcus } \\
\text { pneumoniae }\end{array}$ & \\
\hline Sapkota et al. 2009 [119] & $\begin{array}{l}\text { Not } \\
\text { applicable }\end{array}$ & Cigarettes & & & $\begin{array}{l}\text { Bacillus } \\
\text { Clostridium } \\
\text { Enterococcus } \\
\text { Staphylococcus }\end{array}$ & $\begin{array}{l}\text { Acinetobacter } \\
\text { Burkholderia } \\
\text { Klebsiella } \\
\text { Pseudomonas } \\
\text { aeruginosa } \\
\text { Serratia } \\
\text { Campylobacter } \\
\text { Proteus }\end{array}$ \\
\hline
\end{tabular}

Several different microbial signatures of the phyla Actinobacteria, Bacteroidetes, Firmicutes and Proteobacteria have been found to be altered in humans exposed to cigarette smoke. Arrows indicate an increase $(\uparrow)$ or decrease $(\downarrow)$ in relative abundance in smokers compared to non-smoking subjects. Signatures of Bold microbial genera were found to be present in more than $90 \%$ of all cigarette samples (Additional file 1)

is mostly based on syntrophic (i.e., co-feeding) networks [123]. However, if certain resources are restricted, or niches overlap, competitive interactions can occur between commensals (Fig. 4) and with opportunistic pathogens and the host. These interactions can involve direct and indirect attack of competitors.

For instance, microbes, colonizing the upper airways, have to cope with a scarcity of freely available glucose and iron [124-127]. To overcome these limitations, microbes can either scavenge iron from human cells [124] or release iron-chelating molecules (siderophores) that bind ferric iron from the adjacent environment [128].

Understanding the mechanisms of direct (e.g., secretion of antimicrobial peptides) and indirect microbial competition actions within the URT may illuminate new approaches for the development of new antimicrobial therapies for various diseases, for example, those caused by Staphylococcus aureus or Streptococcus pneumoniae [32, 129-132].

Although studies on microbe-microbe interaction also focus on other abundant genera of the human upper airways [1, 86, 132-138], knowledge on microbial competition for potential treatment of $S$. aureus infections is particularly important. This opportunistic pathogen is an asymptomatic colonizer of human skin and nose but it is also able to cause chronic and indolent to acute and aggressive infections in cases of excessive overgrowth [139-141].

One potentially applicable agent for a putative therapy is secreted by S. lugdunensis, namely lugdunin (a thiazolidine-

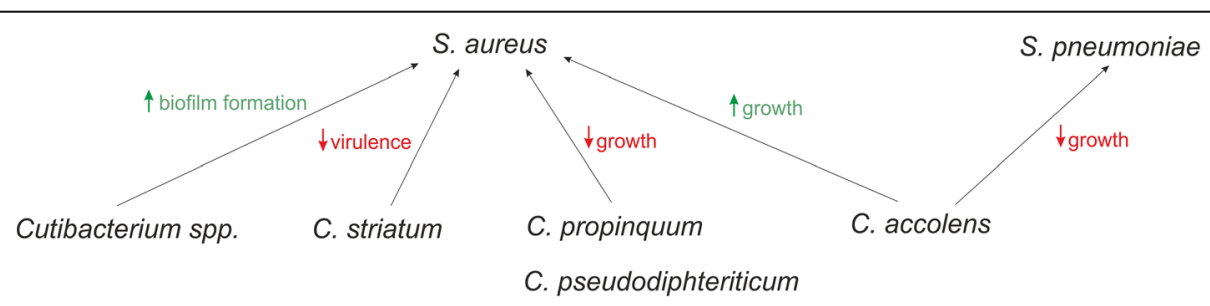

Fig. 4 Influence of nasal microbial community members on each other. Different Corynebacterium spp. are able to inhibit as well as promote growth of staphylococci and S. pneumoniae in vitro, whereas other species led to increased biofilm formation and reduced virulence. For references, see the text 
containing cyclic peptide), which inhibits the growth of $S$. aureus in vitro [142]. Another candidate is the antimicrobial peptide nukacin IVK45, produced by S. epidermidis IVK45 under in vitro oxidative stress and iron limitation [130, 143]. Species- or even strain-specific inhibition or promotion of staphylococci has also been observed for Corynebacteria [32, 129, 130]. Whereas some C. pseudodiphteriticum were able to inhibit the growth of $S$. aureus, co-cultivation with $C$. accolens led to supported and enhanced growth of both strains, indicating a possible cooperative interaction [32].

Corynebacterium species, or even cell-free conditioned medium thereof, were found to shift $S$. aureus towards a more commensal state and attenuation of virulence by downregulation of components involved in colonization and virulence, such as the agr operon or genes involved in hemolytic activity $[129,144,145]$.

In contrast, methionine synthesis and iron acquisition were found to be upregulated in $S$. aureus when cocultured with C. striatum. Based on this observation, Ramsey et al. envisage a competitive situation for methionine and iron in vitro [129]. It should be noted that coagulase-negative staphylococci are more sensitive to these types of nutrient competitions, as they produce lower levels of siderophores; however, resulting growth inhibition has been abolished by providing iron supplementation [124, 130, 146].

Besides Corynebacterium, Cutibacterium spp. (and its cell-free conditioned medium) is also able to affect growth of S. aureus. Coproporphyrin III (CIII), the most abundant porphyrin secreted by Cutibacterium ssp., induces $S$. aureus aggregation and biofilm formation in culture. Therefore, it also might promote biofilm formation with other members of the nostril's microbial community [132, 147, 148].

S. pneumoniae, a common inducer of URT diseases such as pneumonia, sinusitis, or otitis media [131, 149], can be inhibited by $C$. accolens through the production of free fatty acids (FFAs) from the host's triacylglycerols (TAG), causing an increase in the expression of antibacterial human $\beta$-defensin-2 [131, 150, 151].

\section{Non-bacterial microorganisms in the human nose}

Besides bacterial and viral components, the nasal cavity contains a unique, highly diverse archaeal community. Archaea are microorganisms that are, due to their different biology, distinctive from bacteria. They are also relevant components of the human microbiome inhabiting the gastrointestinal tract, oral cavity, skin, and other areas [152]. The archaeal community of the nasal cavity resembles that of the archaeomes of skin and the intestinal tract in being dominated by skin-associated Thaumarchaeota (Nitrososphaera) and also methanogenic Euryarchaeota (Methanosphaera, Methanobrevibacter) which are characteristic of the archaeal communities in the gastrointestinal tract [13]. Notably, the nasal cavity was found to represent an archaeal hot-spot amongst other body sites, with a high archaeal 16S rRNA gene content [153]. The importance of archaea in the nasal cavity was supported by a recent correlation of methano-archaeal presence in refractory sinusitis [154].

Severe knowledge gaps also exist with respect to the mycobiome and virome of the upper respiratory tract; as these fields are not part of this review, we refer readers to some recent reviews on these topics [96, 155-158] (Additional file 1).

\section{Correlations between the upper respiratory tract microbiome and disease}

The anterior nares are an open environment and in contact with several thousands of liters of inhaled air every day [159]. Therefore, besides the gastrointestinal tract, the nasal cavity has been suggested to represent the main entry port for pathogens, pollutants, and pollen, potentially causing imbalances in the nasal microbial community composition $[89,160,161]$. Microbiome dysbiosis is considered an important biomarker for human disease such as chronic rhinosinusitis $[6,162]$.

\section{URT microbiome diversity and specific health-associated} bacteria are reduced in chronic rhinosinusitis

Chronic rhinosinusitis (CRS) is a common chronic and detrimental inflammatory disorder of the human paranasal sinuses. It lasts for more than 12 weeks and affects up to $16 \%$ of the population $[15,163,164]$. Although CRS is suggested to be an inflammatory disease rather than an infectious one, bacterial contributions to the initiation and progression of inflammation are important to consider [165-167].

Previous studies suggested a polymicrobial process behind CRS [168]. A decrease in microbial diversity, richness and evenness, which are frequent features in other chronic inflammatory diseases as well, has been observed in CRS patients in several studies [15, 20, 47, 169-171]. This decline may occur due to an elevated presence of anaerobic bacteria growing in biofilms [172, 173]. Notably, the overall bacterial burden and phylum level abundance were found to remain constant, whereas the relative abundance of specific bacterial genera is altered in CRS patients [171, 174]. Hoggard et al. reported a depletion of signatures of Anaerococcus, Corynebacterium, Finegoldia, Peptoniphilus, Propionibacterium, and Staphylococcus in CRS patients-all previously identified as typical health-associated URT bacteria [162, 170]. This shift away from a healthy microbial community may lead to an increase of both inflammatory response (Toll-like receptor responses) and clinical severity [20, 175] (Table 2; Additional file 1). 
Table 2 The nasal microbiome of chronic rhinosinusitis patients

\begin{tabular}{|c|c|c|c|c|c|c|}
\hline Study & Population & Sample site & Actinobacteria & Bacteroidetes & Firmicutes & Proteobacteria \\
\hline \multirow[t]{2}{*}{ Lal et al. 2017 [29] } & Adults with nasal polyps & $\begin{array}{l}\text { Middle } \\
\text { meatus }\end{array}$ & $\begin{array}{l}\text { Streptococcus } \\
\text { Haemophilus } \\
\text { Fusobacterium }\end{array}$ & & & \\
\hline & $\begin{array}{l}\text { Adults without nasal } \\
\text { polyps }\end{array}$ & $\begin{array}{l}\text { Middle } \\
\text { meatus }\end{array}$ & Corynebacterium & & $\begin{array}{l}\text { Staphylococcus } \\
\text { Alloiococcus }\end{array}$ & \\
\hline $\begin{array}{l}\text { Copeland et al. } 2018 \\
\text { [6] }\end{array}$ & Adults & $\begin{array}{l}\text { Middle } \\
\text { meatus }\end{array}$ & $\downarrow$ Corynebacterium & $\begin{array}{l}\uparrow \text { Porphyromonas } \\
\uparrow \text { Prevotella }\end{array}$ & $\begin{array}{l}\uparrow \text { Anaerococcus } \\
\uparrow \text { Lactobacillus } \\
\uparrow \text { Finegoldia } \\
\uparrow \text { Peptoniphilus } \\
\uparrow \text { Dialister } \\
\uparrow \text { Parvimonas } \\
\downarrow \text { Staphylococcus } \\
\downarrow \text { Dolosigranulum }\end{array}$ & \\
\hline $\begin{array}{l}\text { Hoggard et al. } 2018 \\
\text { [20] }\end{array}$ & Adults & $\begin{array}{l}\text { Middle } \\
\text { meatus }\end{array}$ & $\begin{array}{l}\downarrow \text { Corynebacterium } \\
\downarrow \text { Propionibacterium }\end{array}$ & & $\begin{array}{l}\downarrow \text { Anaerococcus } \\
\downarrow \text { Finegoldia } \\
\downarrow \text { Peptoniphilus } \\
\downarrow \text { Staphylococcus }\end{array}$ & \\
\hline $\begin{array}{l}\text { Aurora et al. } 2013 \\
\text { [176] }\end{array}$ & Adults & $\begin{array}{l}\text { Middle } \\
\text { meatus }\end{array}$ & $\begin{array}{l}\uparrow \text { Corynebacterium } \\
\uparrow \text { Curtobacteria }\end{array}$ & & $\uparrow$ Staphylococcus & $\uparrow$ Pseudomonas \\
\hline $\begin{array}{l}\text { Cope et al. } 2017 \\
{[168]}\end{array}$ & Adults & Sinus & Corynebacteriaceae & & $\begin{array}{l}\text { Staphylococcaceae } \\
\text { Streptococcaceae }\end{array}$ & Pseudomonadaceae \\
\hline
\end{tabular}

Arrows indicate an increase $(\uparrow)$ or decrease $(\downarrow)$ in relative abundance in CRS patients compared to healthy subjects. Relative abundance was analyzed by $16 S$ rRNA sequencing

A study on sinus microbiomes reported that most sinuses of CRS patients are dominated by signatures of Corynebacteriaceae, Pseudomonadaceae, Staphylococcaceae, or Streptococcaceae. These bacterial families were found to co-occur with a unique set of bacterial taxa with lower abundance [168] (Table 2). Other studies showed an overgrowth of Corynebacterium tuberculostearicum and Staphylococcus enrichment in sinuses [15, 169], as well as Corynebacterium, Curtobacteria, Pseudomonas, Staphylococcus, or $H$. influenza enrichment in the middle meatus $[176,177]$ (Table 2).

In the middle meatus, Copeland et al. found a negative correlation of the CRS disease state and six OTUs (operational taxonomic units) affiliated to genera Staphylococcus, Corynebacterium, and Dolosigranulum. Corynebacterium OTU410908 was the only signature to correlate negatively with the SNOT-22 (Sinonasal Outcome Test) score, which states disease severity [6] (Table 2).

Generally, anaerobic genera (Anaerococcus, Lactobacillus, Finegoldia, and Peptoniphilus) were found to be more present in CRS patients' compared to healthy subjects' middle meatuses [6] (Table 2; Additional file 1).

Traditionally, CRS is categorized in two subtypes: CRS with the absence (CRPsNP) or presence (CRPwNP) of nasal polyps (fleshy swellings arising due to inflammation) $[6,15,163]$. Notably, in CRSwNP patients, comorbidities such as aspirin intolerance and asthma are likely to occur [177]. Comparing the inferior and middle meatus microbiome of these different phenotypes reveals that CRSwNP samples were enriched by signatures of Alloiococcus, Staphylococcus, and Corynebacterium spp., whilst CRSsNP patients were enriched mainly by anaerobes, such as Haemophilus, Streptococcus, and Fusobacteria spp., and showed depletion of Rothia, Alloiococcus, Corynebacterium, and Finegoldia. Usually, the sinus cavities are not anaerobic; therefore, this enrichment of anaerobes in CRPsNP subjects is probably a result of disease progression and pathology [178]. Fusobacteria, for example, are associated with suppuration, which can cause anaerobic conditions in the paranasal cavities [29, 176] (Table 2; Additional file 1). Additionally, the severity of inflammation was positively correlated with the phylum Bacteroidetes (e.g., Prevotella) and the phylum Proteobacteria (Pseudomonas) in CRS [179].

Another interesting aspect is that CRS patients have an altered response to taste molecules. They are less sensitive to bitter while being more sensitive to sweet molecules [83]. As described above, bitter receptors in the nose play an important role in bacterial detection and defense. As a result of these alterations CRS patients have less stimulation of ciliary beating in the URT and show altered NO levels $[38,180]$. Notably, It has already been shown that the functional capability of these taste receptors in the URT correlates with severity of CRS [80, 83, 181, 182].

Nasal washes, corticosteroids, and sinus surgery are the most common treatments for CRS and may significantly influence the URT microbiome. The therapy options and their effects are discussed later in this review [21-24].

\section{Nasal microbiome composition may be linked to neurological diseases}

Some reports indicate a potential involvement of the (nasal) microbiome in Parkinson's disease (PD), Alzheimer's disease 
(AD), and multiple sclerosis (MS) [183]. In particular in PD and $\mathrm{AD}$, the first symptoms are olfactory dysfunction (see below), and a link with the nasal microbiome of the olfactory area has been hypothesized as microorganisms contribute to normal development of the olfactory epithelium [184]. Since the nasal microbiome in $\mathrm{AD}$ and MS have not been studied in detail yet, we herein concentrate on PD as an example. $\mathrm{PD}$ is a neurodegenerative disease that is characterized by clumping of the protein $\alpha$-synuclein in neuronal cells. In the dopaminergic substantia nigra of the central nervous system (CNS), these aggregates, also called Lewy bodies, lead to neuronal loss $[185,186]$. $\alpha$-Synuclein pathology was found to affect olfactory bulb function [160, 185, 186], and more than $90 \%$ of PD patients suffer from decreased olfactory function or hyposmia, even before motor symptoms occur [187].

Some studies suggested that a failure in innate immune system priming by nasopharyngeal microbiota could lead to an inflammatory response to $\alpha$-synuclein, oxidative stress, cross-seeded misfolding, and thus development of neurodegenerative diseases [188-191]. Therefore, the studies hypothesized that the microbial community contributes to the initiation of PD $[187,192,193]$.

No significant differences in alpha and beta diversity between the nasal microbiome of PD patients and healthy participants had until now been observed [192]. However, Pereira et al. showed that two taxa were less abundant in PD patients compared to healthy controls, namely signatures of the family Flavobacteriaceae and the genus Marmoricola [192] (Additional file 1).

Other studies hypothesize that a currently unknown, transmissible infectious agent enters the brain through the gastrointestinal tract and/or the nasal cavity and initiates the pathological process in the CNS $[160,193]$.

However, this research is at an early stage and the importance of the microbial community in initiation of PD requires further investigation.

\section{The respiratory tract microbiome of cystic fibrosis patients follows clear patterns and might be established already early in life}

Cystic fibrosis (CF) is a hereditary life-limiting disease that is caused by mutations in the gene of the cystic fibrosis transmembrane conductance regulator (CFTR). It can affect diverse organs but in most cases results in chronic lung disease $[117,120]$, characterized by a defect in mucociliary clearance and mucopurulent secretions [194-197]. The lungs of CF patients are colonized with so called "typical CF pathogens" consisting of bacterial genera Rothia, Prevotella, Streptococcus, Actinomyces, and Veillonella [195, 198, 199]. In addition to this socalled CF core microbiota, other CF-associated pathogens like Pseudomonas aeruginosa, Haemophilus influenza, Burkholderia cepacia complex, and Staphylococcus aureus can lead to chronic lung infection in CF $[16,194$,
195]. The microorganisms originating from the environment probably spread via inhalation or micro-aspiration from the upper respiratory tract (URT) into the lungs $[194,200]$. Several studies also demonstrate that the nasal cavity and the nasopharynx act as a reservoir for further colonization of these potential respiratory pathogens (PRPs), before they spread in the lower airways [26, 201, 202] (Additional file 1).

In CF infants, the nasal microbiome shows significant differences when compared to healthy controls. For instance, the relative abundance of Corynebacteriaceae and Pastorellaceae signatures was found to be reduced in the nasal microbiome of CF infants, whereas the relative abundance of Staphylococcaceae was increased. In nasopharyngeal samples, S. mitis, Corynebacterium accolens, and S. aureus as well as Gram-negative bacteria were more abundant in CF children [90]. This increased abundance of $S$. aureus in CF infants in early life is probably caused by a defect of the early innate immune system; moreover, due to accumulation of mucus, microaerobic conditions prevail in the airways of CF patients, which could lead to a better survival of $S$. aureus [26, 203, 204]. The URT microbiome of CF children adult CF patients is very similar, indicating establishment of this abnormal microbiome early in life [194] (Additional file 1).

\section{Nasal microbiome in olfactory function and dysfunction}

The functional area of human olfaction in the nose is the olfactory mucosa, which is located at the ceiling of the nasal cavity, is 8 to $10 \mathrm{~mm}$ long, and extends from the septum to the middle and superior turbinate. This olfactory area is characterized by a high abundance of bipolar neurons from the olfactory nerve and the presence of lactoferrin, IgA, IgM, and lysozyme, which prevent pathogens from intracranial entry through the cribriform plate [205].

The olfactory receptor cells in the olfactory mucosa pass through the cribriform plate into the olfactory bulb of the CNS. These cells are able to recognize different odor molecules, but also secondary metabolites of bacteria [33, 206]. In general, microbes are known to be able to interact with human body tissues via secondary metabolites, including short-chain fatty acids and other, hormone-like molecules [207-209].

Most cases of olfactory loss occur secondary to inflammation (caused, for example, by viral infections or chronic rhinosinusitis), traumatic brain injuries, ageing, or neurodegenerative diseases (e.g., PD and Alzheimer's disease) $[210,211]$. In addition, as the physiology of the olfactory epithelium can be modulated by the microbiome, an influence of the microbial composition on olfactory function and dysfunction has been suggested $[43,184]$. 
In healthy, normosmic volunteers Koskinen et al. identified four archaeal and 23 bacterial phyla in the microbiome of the olfactory area, the latter with Actinobacteria, Firmicutes, Proteobacteria, and Bacteroidetes predominating. On the genus level, signatures of Corynebacterium, Staphylococcus, and Dolosigranulum were shown to be most abundant [43]. Corynebacterium and Staphylococcus are typical human skin bacteria, frequently found in the nasal cavity [1, 134, 138, 212, 213]. Dolosigranulum has been observed to be a healthassociated commensal inhabitant [139], but Dolosigranulum pigrum, an opportunistic pathogen, can, under certain conditions, also cause infections [214, 215] (Additional file 1).

Besides the healthy, normosmic participants, subjects with different olfactory performance were also studied [43]. Olfactory performance can be assessed by three different metrics: odor threshold ( $\mathrm{T}$; lowest concentration of odor compound perceivable), odor discrimination ( $\mathrm{D}$; discrimination of different odors), and odor identification (I; identification/naming of a certain odor). Based on these scores an overall TDI score is calculated. This TDI score categorizes subjects as normosmics (with normal olfactory performance), hyposmics (with decreased olfactory function), and anosmics (complete loss of olfactory function) [216, 217].

It is thought that an impacted nasal airflow influences the URT microbiome indirectly by changing local parameters (such as humidity, temperature, oxygenation). Such impacted airflow can occur due to rhinosinusitis, allergic rhinitis, head trauma, nasal surgery or congenital causes [33, 218-220] and might also contribute to the decrease in olfactory function by affecting the microbial community structure.

Indeed, Koskinen et al. observed that the microbiome of hyposmic subjects differed significantly in community composition and diversity compared to normosmics [43]. Odor threshold hyposmics (people with poor $\mathrm{T}$ score) showed a higher microbial diversity at the olfactory area, for example, signatures of the genus Campylobacter were found to correlate negatively with this condition, whereas Proteobacteria, Actinobacteria, Firmicutes, and Bacteroidetes were associated with poor odor identification. Furthermore, butyrate-producing bacteria like Faecalibacterium correlated negatively with odor threshold and discrimination, Enterobacteriaceae correlated negatively with odor threshold and identification, and Porphyromonas and unclassified Lachnospiraceae correlated negatively with overall olfactory performance (T, D, I) [43]. Whereas Porphyromonas is a typical representative of the human oral microbiome, Faecalibacterium, Enterobacteriaceae, and Lachnospiraceae are gut microorganisms, capable of producing butyrate. As butyrate has a very strong and unpleasant odor, and the production is out of place in the nasal area, it was suggested that it may have an impact on olfactory performance [43, 167, 221] (Additional file 1).

Analyzing the microbial composition and abundance with the goal of providing therapy options (e.g., through probiotics) could be one possible way to improve life quality for the $20 \%$ of the general population suffering from olfactory dysfunction.

\section{Therapies change the URT microbiome composition and diversity}

Intranasal corticosteroids (INS), saline rinses, antihistamines, and antibiotics are the current medical therapies of choice for inflammatory disorders of the upper respiratory tract $[21,24]$. In contrast to anti-inflammatory substances that act through immunomodulatory mechanisms, antibiotics and some INS have antimicrobial properties and thus impact the microbial community directly $[24,222]$.

\section{Antibiotics and other intranasal medication}

Antibiotics and other medication with antimicrobial properties are usually used to treat severe bacterial infections. However, in some cases they are applied prophylactically, for example, before sinus surgery to diminish the bacterial load in the nasal cavity [24].

Application of antibiotics has been shown to influence microbial community composition significantly by reducing the microbial diversity not only in the gut, but also in the upper respiratory tract of infants and adults. The shift in the URT microbial profile results in an increased abundance of Gram-negative bacteria (Burkholderia, Comamonadaceae, Bradyrhizobiaceae, and Enterobacteriaceae) as well as Moraxella, Haemophilus, Staphylococcus, and Streptococcus [25-27]. Under normal circumstances, these bacteria are unable to compete in this niche, but due to tolerance to several antibiotics (e.g., $H$. influenza and Chlamydia pneumoniae: resistance towards $\beta$-lactam antibiotics; S. pneumoniae: resistance towards aminoglycosides, fluroquinolones, and $\beta$-lactam) they are able to expand during antibiotic treatment and become pathogenic [223, 224]. In contrast, abundances of known commensals such as Dolosigranulum and Corynebacterium, which normally are highly abundant in the human nose and associated with decreased URT infection risk and microbiota stability, are reduced by the treatment. These shifts in the anterior nares microbiome lasted throughout treatment and even posttreatment period (at least 2 weeks after treatment) [24, 93].

Topical antibiotic therapy with, e.g., mupirocin is used as standard preoperative therapy for non-allergic rhinitis (i.e., chronic rhinosinusitis). It has been shown that antibiotic treatment with muropirocin was able to decolonize $S$. aureus preoperatively, decreasing $S$. aureus site infections in surgery $[24,225,226]$. 
INSs like mometasone furoate monohydrate, which has anti-inflammatory properties, are common first line therapies for allergic rhinitis (AR) [21, 24]. INSs affect the composition and biodiversity of the nasal microbiome: like antibiotics, this medication suppresses several taxa (Moraxella spp., streptococci) and may promote the dominance of other taxa such as staphylococci $[24,225,226]$.

\section{Alterations in nasal structure due to sinus surgery influence the microbial community in the nasal cavity} Endoscopic sinus surgery (ESS) is an invasive treatment mainly used for polyposis and refractory sinusitis [22]. It enlarges the size of sinus ostia, improves mucociliary clearance, and facilitates access for topical therapies [218]. This intervention changes the physical sinus structure and may influence paranasal physiology by reducing the temperature and humidity in the nasal cavity. This drier and cooler post-operative ecosystem might have an effect on microbial composition and metabolism [218, 227].

Overall, the post-operative outcome of the surgery is positive, and only a subset of the patients does not recover $[28,228]$. This subset suffers from a recolonization by pathogens despite antibiotic treatment after surgery [229-231]. It is suggested that the repopulation has its origins in paranasal sinus biofilms or in the nasopharynx, as these areas are better protected from antibiotics $[164,229,232,233]$. It has also been reported that CRP patients who suffer from inflammation after the surgery have higher numbers of SCCs in the URT inflamed tissue [66]. Furthermore, patients with the non-functional genetic variation of the bitter receptor T2R38 are more likely to need surgery and develop bacterial infections $[82,83]$.

Notably, Hauser et al. found that the bacterial load of the ethmoid is lower at the time of surgery and 6 weeks after surgery than in the postoperative period ( 2 weeks after surgery). The authors suggested that a broad disruption of immune function and the mucociliary system due to the surgical intervention is responsible for this altered bacterial burden [229].

In an independent study, Jain et al. [218] reported an increase in the number of bacterial signatures, but no change in overall microbial profile 4 months after surgery compared to pre-operative microbial profiles. However, the relative abundance of Staphylococcus signatures increased whereas Streptococcus and Corynebacterium decreased; most changes were observed in extremely low-abundance taxa (e.g., Peptoniphilus, Finegoldia, Faecalibacterium, Campylobacter) [218].

Other studies reported similarities between the bacterial community of the ethmoid and sinuses after surgery and those of the anterior nasal cavity and pretreatment sinuses, and also the presence of bacteria from extra nasal sources, suggesting that all these sites serve as likely sources for recolonization [164, 229, 233, 234].

\section{Nasal rinse might be a microbiome-friendly alternative to aggressive therapy options for URT diseases/problems} Nasal rinse has its origins in Ayurveda, an ancient, traditional system of Indian healthcare [235]. Today, nasal rinse is not only used to treat upper respiratory tract problems, as URTIs, CRS, or AR, but also as prevention of those diseases. Nasal irrigation is thought to clean the nasal mucosa from inflammatory mediators like leukotrienes and prostaglandins, antigens, and other pollutants [23, 236, 237]. The most common rinsing solutions are isotonic saline $(0.9 \%)$ or hypertonic saline $(1.5-3 \%), \mathrm{pH}$ varying from 4.5 to 7 , but distilled, tap, and well-water is also used [23, 238].

The potential microbial contamination of irrigation water and devices has been of concern, as it might contain S. aureus and Pseudomonas spp. which cause the majority of postoperative infections [234, 238, 239]. However, these low abundance contaminations showed only little impact on microbial composition in the human sinonasal cavity [240]. Nevertheless, distilled water is recommended, as tap water and well-water can also lead to mycobacterial infections and amebic brain abscesses [238, 241, 242].

The high frequency of positive results of nasal irrigation in several studies indicates that nasal rinsing is an effective, inexpensive, and simple method to treat sinonasal disorders alone or in association with other therapies to reduce medicine consumption.

\section{Probiotics might be a non-invasive disease prevention and therapy option}

In many cases of asthma and CRS, microbial dysbiosis is manifested by the expansion of pathogens and the loss of beneficial microorganisms [243, 244]. Living beneficial bacteria (probiotics) administered in adequate amounts can provide health benefits to the host [19, 245, 246]. Probiotic species may act as pioneers after disruption due to antibiotics, or have a larger beneficial effect on the community by acting as keystone species [247]. Additionally, probiotic strains may even be able to improve the epithelial barrier (by modulation of signaling pathways [248, 249]) or to interact positively with the host innate immune system $[245,246,250,251]$. Probiotic microbes can interact with other microbes of the human microbiome by production of antimicrobials, competitive colonization, and inhibition of pathogen growth (e.g., by changing the $\mathrm{pH}$ in the niche) [247, 252, 253]. Probiotic bacteria can have various immunomodulatory functions, including $\mathrm{T}$ helper cell 1 (Th1)/T helper cell 2 (Th2) immune balance restoration, stimulation of regulatory $\mathrm{T}$ cells (Treg), the regulation of regulatory 
cytokines [254-257], and also the modulation of allergen-specific $\mathrm{T}$ - and $\mathrm{B}$-cell responses and mucosal IgA levels [258].

Immune cells, microbial metabolites, and cytokines released due to oral probiotic supplementation reach the airways through translocation into the blood and systemic circulation, whereas probiotics applied via nasal sprays affect the local immune response and the sinonasal microbiome [259-263]. For example, Lactobacillus rhamnosus leads to an increase in Th1 and decrease in Th2 levels in mice [264, 265], and treatment of acute sinusitis in children with Enterococcus faecalis has already been shown to reduce frequency and duration of sinusitis [246, 266].

The next logical step would be the application of probiotics nasally, although a potential risk of inflammation in the lower airways due to aspiration into the lung might exist [246, 267]. However, Martensson et al. were able to show, although no significant effects on CRS disease progression were observed, that nasal application of 13 honeybee lactic acid bacteria (various Bifidobacteria and lactobacilli of the honey stomach of Apis mellifera) was well tolerated by patients. This probiotic was able to restore commensal microbiomes and to prevent infections through antibacterial activity. Furthermore, no side effects could be observed [246, 268-272].

\section{Knowledge gaps, conclusion, and outlook}

Research on the microbiome of the URT has already revealed insights into its dynamic niche-specific composition, interactions between microbes and the host's immune, olfactory, and chemosensory systems, and alterations that are associated with age, lifestyle and disease. This research is, however, still in its infancy. The majority of current knowledge about the URT microbiome is based on cultivation assays, targeting only a fraction of the microbial community, or next generation sequencing of segments of the bacterial 16S rRNA gene amplified from uncultured samples. These short reads provide basic information about the diversity and taxonomic composition of bacterial communities. However, more accurate species or strain level community profiling can now be achieved using, for example, long-read technologies for sequencing the entire 16S rRNA gene, such as Oxford Nanopore [273] or Pacific Bioscience (PacBio) technology [274], which has already been successfully applied to analysing the healthy sinonasal microbiome [275]. Shot-gun metagenomics is another approach that is increasingly used in microbiome research, offering insights into microbial genomes and functions, and the possibility to assemble draft genomes of uncultured human health or disease associated microbes. Untargeted shot-gun metagenomics could also give unbiased insights into the archaeome, mycobiome and virome of the URT, although due to the low abundance of many of these components, targeted approaches could be more effective in capturing their full diversity.

Determining whether the detected changes or dysbioses in the URT microbiome associated with disease are markers or drivers presents a major challenge. There has already been some progress towards identifying biomarkers that could be used for early diagnosis of URTIs, such as Microbacterium spp., Streptococcus spp. or Faecalibacterium spp., whereas identifying targets for microbiome-based therapies remains more difficult. The ability to sample from disease-relevant sites within the URT is helpful in this regard, as it enables the identification of microbial candidate disease drivers whose abundance is positively correlated with both the site and incidence of disease, while negative correlations reported from the disease site are similarly more likely to be relevant, pointing to a possible protective role that might be harnessed in probiotic therapy. It will therefore be important to address the methodological challenges of sampling from less accessible URT sites, and to continue to develop appropriate sampling tools to minimise contamination from neighbouring sites. Further investigation of the co-operative and competitive interactions of microbes and host may also be helpful in guiding rational choices in the pursuit of causal connections and therapeutic goals. However, establishing causality and demonstrating the efficacy of proposed treatments requires other approaches, such as animal models and clinical trials.

Physicians and patients have high expectations of microbiome-driven therapies, yet most available knowledge stemming from basic research or clinical trials is far from impacting, or being implemented in, medical treatment. The results we have surveyed in this review suggest there are good reasons to remain optimistic about therapeutic solutions emerging from URT microbiome research, especially as newly available methodologies are deployed and current knowledge gaps are filled.

\section{Supplementary information}

Supplementary information accompanies this paper at https://doi.org/10. 1186/s12915-019-0703-z.

Additional file 1. Summary of the URT microbiome during the process of aging and in health and disease (collated information from selected studies).

\footnotetext{
Abbreviations

URT: Upper respiratory tract; URTI: URT infections; CRS: Chronic rhinosinusitis; AN: Anterior nares; MM: Middle meatus; OR: Olfactory area;

SR: Sphenoethmoidal recess; COPD: Chronic obstructive pulmonary disease; OTU: Operational taxonomic unit; CRPsNP: CRS with the absence of nasal polyps; CRPwNP: CRS with the presence of nasal polyps; PD: Parkinson's disease; CNS: Central nervous system; CF: Cystic fibrosis; CFTR: Cystic fibrosis transmembrane conductance regulator; PRPs: Potential respiratory pathogens; Ig: Immunoglobulin; T: Odor threshold; D: Odor discrimination; I: Odor identification; INS: Intranasal corticosteroids; ESS: Endoscopic sinus surgery; AR: Allergic rhinitis; GIT: Gastrointestinal tract; NGS: Next generation sequencing
} 


\section{Acknowledgements}

We gratefully acknowledge the support of Florian Fischmeister, University of Graz, Austria.

Funding: We acknowledge funding by the FWF (KLI 639) given to Veronika Schöpf (PI) and Christine Moissl-Eichinger (Co-PI). CK was supported by the local PhD program MolMed. KK, VS, and CME were supported by BioTechMed-Graz, the cooperation and networking initiative of the three major universities in Graz.

\section{Authors' contributions}

CK performed literature research and wrote the manuscript. KK and CME supervised literature research and wrote the manuscript. VS critically discussed and corrected the final draft. All authors read and approved the final manuscript.

\section{Availability of data and materials}

Not applicable.

\section{Competing interests}

The authors declare that they have no competing interests.

\section{Author details}

'Diagnostic and Research Institute of Hygiene, Microbiology and Environmental Medicine, Medical University of Graz, Neue Stiftingtalstraße 6, 8010 Graz, Austria. ${ }^{2}$ Institute of Psychology, University of Graz, Universitaetsplatz 2, 8010 Graz, Austria. ${ }^{3}$ BioTechMed-Graz, Mozartgasse 12/ll, $8010 \mathrm{Graz}$, Austria. ${ }^{4}$ Present address: Medical University Vienna, Spitalgasse 23, 1090 Vienna, Austria.

Received: 19 September 2019 Accepted: 19 September 2019 Published online: 07 November 2019

\section{References}

1. Costello EK, Lauber CL, Hamady M, Fierer N, Gordon JI, Knight R. Bacterial community variation in human body habitats across space and time. Science. 2009;326:1694-7. https://doi.org/10.1126/science.1177486.

2. Lloyd-Price J, Mahurkar A, Rahnavard G, Crabtree J, Orvis J, Hall AB, et al. Strains, functions and dynamics in the expanded Human Microbiome Project. Nature. 2017;550:61. https://doi.org/10.1038/nature23889.

3. de Steenhuijsen Piters WAA, Sanders EAM, Bogaert D. The role of the local microbial ecosystem in respiratory health and disease. Philos Trans R Soc B Biol Sci. 2015;370:20140294. https://doi.org/10.1098/rstb.2014.0294.

4. Dickson R, Erb-Downward J, Martinez F, Huffnagle G. The microbiome and the respiratory tract. HHS Public Access. 2017:78:481-504.

5. Lighthart B. Mini-review of the concentration variations found in the alfresco atmospheric bacterial populations. 2000. https://ink.springer.com/ content/pdf/10.1023\%2FA\%3A1007694618888.pdf. Accessed 22 Oct 2018.

6. Copeland E, Leonard K, Carney R, Kong J, Forer M, Naidoo Y, et al. Chronic rhinosinusitis: Potential role of microbial dysbiosis and recommendations for sampling sites. Front Cell Infect Microbiol. 2018;8:57. https://doi.org/10.3389/ fcimb.2018.00057.

7. Dominguez-Bello MG, Costello EK, Contreras M, Magris M, Hidalgo G, Fierer $\mathrm{N}$, et al. Delivery mode shapes the acquisition and structure of the initial microbiota across multiple body habitats in newborns. Proc Natl Acad Sci U S A. 2010:107:11971-5. https://doi.org/10.1073/pnas.1002601107.

8. de Steenhuijsen Piters WAA, Huijskens EGW, Wyllie AL, Biesbroek G, Van Den Bergh MR, Veenhoven RH, et al. Dysbiosis of upper respiratory tract microbiota in elderly pneumonia patients. ISME J. 2016;10:97-108.

9. Whelan FJ, Verschoor CP, Stearns JC, Rossi L, Luinstra K, Loeb M, et al. The loss of topography in the microbial communities of the upper respiratory tract in the elderly. Ann Am Thorac Soc. 2014;11:513-21.

10. Bassis CM, Tang AL, Young VB, Pynnonen MA. The nasal cavity microbiota of healthy adults. Microbiome. 2014;2:27.

11. Shilts MH, Rosas-Salazar C, Tovchigrechko A, Larkin EK, Torralba M, Akopov $A$, et al. Minimally Invasive sampling method identifies differences in taxonomic richness of nasal microbiomes in young infants associated with mode of delivery. Microb Ecol. 2016;71:233-42

12. Stearns JC, Davidson CJ, Mckeon S, Whelan FJ, Fontes ME, Schryvers AB, et al. Culture and molecular-based profiles show shifts in bacterial communities of the upper respiratory tract that occur with age. ISME J. 2015;9:1246-59. https://doi.org/10.1038/ismej.2014.250
13. Koskinen K, Pausan MR, Perras AK, Bang MBC, Mora M, Schilhabel A, et al. First insights into the diverse human archaeome: Specific detection of archaea in the gastrointestinal tract. MBio. 2017;8:1-17.

14. Vayssier-Taussat M, Albina E, Citti C, Cosson J-F, Jacques M-A, Lebrun M-H, et al. Shifting the paradigm from pathogens to pathobiome: new concepts in the light of meta-omics. Front Cell Infect Microbiol. 2014;4:29. https://doi. org/10.3389/fcimb.2014.00029.

15. Abreu NA, Nagalingam NA, Song Y, Roediger FC, Pletcher SD, Goldberg AN, et al. Sinus microbiome diversity depletion and Corynebacterium tuberculostearicum enrichment mediates rhinosinusitis. Sci Transl Med. 2012; 4:151ra124. https://doi.org/10.1126/scitransImed.3003783.

16. Coburn B, Wang PW, Diaz Caballero J, Clark ST, Brahma V, Donaldson S, et al. Lung microbiota across age and disease stage in cystic fibrosis. Sc Rep. 2015;5:10241. https://doi.org/10.1038/srep10241.

17. Gevers $D$, Kugathasan S, Denson LA, Vázquez-Baeza Y, Van Treuren W, Ren $B$, et al. The treatment-naive microbiome in new-onset Crohn's disease. Cell Host Microbe. 2014;15:382-92. https://doi.org/10.1016/j. chom.2014.02.005.

18. Hartstra AV, Bouter KEC, Bäckhed F, Nieuwdorp M. Insights into the role of the microbiome in obesity and type 2 diabetes. Diabetes Care. 2015;38:15965. https://doi.org/10.2337/dc14-0769.

19. Petersen C, Round JL. Microreview Defining dysbiosis and its influence on host immunity and disease. Cell Microbiol. 2014;16:1024-33.

20. Hoggard M, Waldvogel-Thurlow S, Zoing M, Chang K, Radcliff FJ, Wagner Mackenzie $B$, et al. Inflammatory endotypes and microbial associations in chronic rhinosinusitis. Front Immunol. 2018;9:2065. https://doi.org/10.3389/ fimmu.2018.02065.

21. Bernstein JA. Characterizing rhinitis subtypes. Am J Rhinol Allergy. 2013;27: 457-60. https://doi.org/10.2500/ajra.2013.27.3983.

22. Ginat DT. Posttreatment imaging of the paranasal sinuses following endoscopic sinus surgery. Neuroimaging Clin N Am. 2015;25:653-65. https:// doi.org/10.1016/J.NIC.2015.07.008.

23. Principi N, Esposito S. Nasal irrigation: an imprecisely defined medical procedure. Int J Environ Res Public Health. 2017:14. https://doi.org/10.3390/ ijerph14050516.

24. Ramakrishnan VR, Holt J, Nelson LF, Ir D, Robertson CE, Frank DN Determinants of the nasal microbiome: pilot study of effects of intranasal medication use. Allergy Rhinol (Providence). 2018:9: 2152656718789519. https://doi.org/10.1177/2152656718789519.

25. Feazel LM, Robertson CE, Ramakrishnan VR, Frank DN. Microbiome Complexity and Staphylococcus aureus in chronic rhinosinusitis. Laryngoscope. 2012;122:467-72. https://doi.org/10.1002/lary.22398.

26. Prevaes SMPJ, De Winter-De Groot KM, Janssens HM, De Steenhuijsen Piters WAA, Tramper-Stranders GA, Wyllie AL, et al. Development of the nasopharyngeal microbiota in infants with cystic fibrosis. Am J Respir Crit Care Med. 2016;193:504-15.

27. Teo SM, Mok D, Pham K, Kusel M, Serralha M, Troy N, et al. The infant nasopharyngeal microbiome impacts severity of lower respiratory infection and risk of asthma development. Cell Host Microbe. 2015:17:704-15. https:// doi.org/10.1016/j.chom.2015.03.008.

28. Smith TL, Litvack JR, Hwang PH, Loehrl TA, Mace JC, Fong KJ, et al. Determinants of outcomes of sinus surgery: a multi-institutional prospective cohort study. Otolaryngol Head Neck Surg. 2010;142:55-63. https://doi.org/ 10.1016/j.otohns.2009.10.009.

29. Lal D, Keim P, Delisle J, Barker B, Rank MA, Chia N, et al. Mapping and comparing bacterial microbiota in the sinonasal cavity of healthy, allergic rhinitis, and chronic rhinosinusitis subjects. Int Forum Allergy Rhinol. 2017;7: 561-9. https://doi.org/10.1002/alr.21934.

30. Luna PN, Hasegawa K, Ajami NJ, Espinola JA, Henke DM, Petrosino JF, et al. The association between anterior nares and nasopharyngeal microbiota in infants hospitalized for bronchiolitis. Microbiome. 2018;6:1-14.

31. Zhou Y, Mihindukulasuriya KA, Gao H, La Rosa PS, Wylie KM, Martin JC, et al. Exploration of bacterial community classes in major human habitats. Genome Biol. 2014;15:R66.

32. Yan M, Pamp SJ, Fukuyama J, Hwang PH, Cho D-Y, Holmes S, et al. Nasal microenvironments and interspecific interactions influence nasal microbiota complexity and S. aureus carriage. Cell Host Microbe. 2013; 14:631-40.

33. Sahin-Yilmaz A, Naclerio RM. Anatomy and physiology of the upper airway. Proc Am Thorac Soc. 2011;8:31-9. https://doi.org/10.1513/pats.201007O5ORN. 
34. Jones $\mathrm{N}$. The nose and paranasal sinuses physiology and anatomy. Adv Drug Deliv Rev. 2001;51:5-19. https://doi.org/10.1016/S0169409X(01)00172-7.

35. Geurkink N. Nasal anatomy, physiology, and function. J Allergy Clin Immunol. 1983;72:123-8.

36. Jimenez PN, Koch G, Thompson JA, Xavier KB, Cool RH, Quax WJ. The multiple signaling systems regulating virulence in Pseudomonas aeruginosa. Am Soc Microbiol. 2012;76:46-65.

37. Li Z, Nair SK. Quorum sensing: how bacteria can coordinate activity and synchronize their response to external signals? Protein Sci. 2012;21:1403-17.

38. Patel NN, Workman AD, Cohen NA. Role of taste receptors as sentinels of innate immunity in the upper airway. J Pathog. 2018;2018:9541987.

39. Cohen N. Sinonasal mucociliary clearance in health and disease. Ann Otol Rhinol Laryngol Suppl. 2006;196:20-6 wuw.ncbi.nlm.nih.gov/pubmed/17040014.

40. Ali M. Histology of the human nasopharyngeal mucosa. J Anat. 1965;99: 657-72 https://europepmc.org/backend/ptpmcrender.fcgi?accid=PMC12 70703\&blobtype=pdf. Accessed 5 Nov 2018.

41. Bell GW, Joshi BB, Macleod RI. Maxillary sinus disease: diagnosis and treatment. Br Dent J. 2011;210:113-8. https://doi.org/10.1038/sj.bdj.2011.47.

42. Proctor DM, Relman DA, Section D, Alto P. The landscape ecology and microbiota of the human nose, mouth and throat. Cell Hot Microbe. 2018; 21:421-32.

43. Koskinen K, Reichert JL, Hoier S, Schachenreiter J, Duller S, Moissl-Eichinger C, et al. The nasal microbiome mirrors and potentially shapes olfactory function. Sci Rep. 2018;8:1-11.

44. Shroff K, Meslin K, Cebra J. Commensal enteric bacteria engender a selflimiting humoral mucosal immune response while permanently colonizing the gut. Infect Immun. 1995;63:3904-13.

45. Casado B, Pannell LK, ladarola P, Baraniuk JN. Identification of human nasal mucous proteins using proteomics. Proteomics. 2005;5:2949-59.

46. Wanner A, Salathé M, O'Riordan T. Mucociliary clearance in the airways. Am J Respir Crit Care Med. 1996;154:1868-902.

47. Schenck LP, Surette MG, Bowdish DME. Composition and immunological significance of the upper respiratory tract microbiota. FEBS Lett. 2016;590: 3705-20.

48. Ooi EH, Wormald PJ, Tan LW. Innate immunity in the paranasal sinuses: a review of nasal host defenses. Am J Rhinol. 2008;22:13-9.

49. Devine DA, Marsh PD, Meade J. Modulation of host responses by oral commensal bacteria. J Oral Microbiol. 2015;7:26941.

50. Ivanov I, Honda K. Intestinal commensal microbes as immune modulators. Cell Host Microbe. 2012;12:496-508.

51. Ganz T. Antimicrobial polypeptides in host defense of the respiratory tract. J Clin Invest. 2002:109:693-7.

52. Sanchez L, Calvo M, Brock JH. Biological role of lactoferrin. Arch Disease Child. 1992;67:657-61.

53. Klebanoff SJ. Myeloperoxidase: friend and foe. J Leukoc Biol. 2005;77:598-625

54. Nauseef WM. Assembly of the phagocyte NADPH oxidase. Histochem Cell Biol. 2004;122:277-91.

55. Thomas EL, Aune TM. Lactoperoxidase, peroxide, thiocyanate antimicrobial system: correlation of sulfhydryl oxidation with antimicrobial action. Infect Immun. 1978;20:456-63.

56. Lee RJ, Xiong G, Kofonow JM, Chen B, Lysenko A, Jiang P, et al. T2R38 taste receptor polymorphisms underlie susceptibility to upper respiratory infection. J Clin Invest. 2012;122:4145-59.

57. Parker D, Prince A. Innate immunity in the respiratory epithelium. Am J Respir Cell Mol Biol. 2011;45:189-201.

58. Salathe M. Regulation of mammalian ciliary beating. Annu Rev Physiol. 2007; 69:401-22.

59. Harabuchi $Y$, Hamamoto M, Shirasaki H, Asakura K, Matsuyama H, Kataura A. Specific immune response of the adenoids to a respiratory antigen. Am J Otolaryngol. 1989;10:138-42.

60. Rynnel-Dagöö B. The immunological function of the adenoid. The proportions of T and B cells. Acta Otolaryngol. 1976;82:196-8.

61. Graeme-cook F, Bhan AK, Harris NL. Immunohistochemical characterization of intraepithelial and subepithelial mononuclear cells of the upper airways. Am J Pathol. 1993;143:1416-22

62. Brandtzaeg P. Role of J chain and secretory component in receptormediated glandular and hepatic transport of immunoglobuiins in man. Scand J Immunol. 1985;22:111-46.

63. Van Kempen MJP, Rijkers GT, Van Cauwenberge PB. The immune response in adenoids. Int Arch Allergy Immunol. 2000;122:8-19.
64. Tang X, Hori S, Osamura R, Tsutsumi Y. Reticular crypt epithelium and intraepithelial lymphoid cells in the hyperplastic human palatine tonsil: an immunohistochemical analysis. Pathol Int. 1995;45:34-44.

65. des Rieux A, EGE R, Gullberg E, Préat V, Schneider Y-J, Artursson P. Transport of nanoparticles across an in vitro model of the human intestinal follicle associated epithelium. Eur J Pharm Sci. 2005;25:455-65.

66. Patel NN, Kohanski MA, Maina IW, Triantafillou V, Workman AD, Tong CCL, et al. Solitary chemosensory cells producing interleukin-25 and group-2 innate lymphoid cells are enriched in chronic rhinosinusitis with nasal polyps. Int Forum Allergy Rhinol. 2018;8:900-6.

67. Kato A, Schleimer RP. Beyond inflammation: airway epithelial cells are at the interface of innate and adaptive immunity. Curr Opin Immunol. 2007;19: 711-20.

68. Liao B, Cao P, Zeng M, Zhen Z, Wang H, Zhang Y, et al. Interaction of thymic stromal lymphopoietin, IL-33, and their receptors in epithelial cells in eosinophilic chronic rhinosinusitis with nasal polyps. Eur J Allergy Clin Immunol. 2015;70:1169-80.

69. Finger TE, Böttinger B, Hansen A, Anderson KT, Alimohammadi H, Silver WL. Solitary chemoreceptor cells in the nasal cavity serve as sentinels of respiration. Proc Natl Acad Sci U S A. 2003;100:8981-6.

70. Rivière $\mathrm{S}$, Challet L, Fluegge $\mathrm{D}$, Spehr M, Rodriguez I. Formyl peptide receptor- like proteins are a novel family of vomeronasal chemosensors. Nature. 2009;459:574-7.

71. Liberles SD, Horowitz LF, Kuang D, Contos JJ, Wilson KL, Siltberg-Liberles J, et al. Formyl peptide receptors are candidate chemosensory receptors in the vomeronasal organ. Proc Natl Acad Sci U S A. 2009;106:9842-7.

72. Alarie $Y$. Irritating properties of airborne materials to the upper respiratory tract. Arch Env Heal. 1966;13:433-49.

73. Tizzano M, Gulbransen BD, Vandenbeuch A, Clapp TR, Herman JP, Sibhatu HM. Nasal chemosensory cells use bitter taste signaling to detect irritants and bacterial signals. Proc Natl Acad Sci U S A. 2010;107:3210-5.

74. Geppetti P, Materazzi S, Nicoletti P. The transient receptor potential vanilloid 1: role in airway inflammation and disease. Eur J Pharmacol. 2006;533:207-14.

75. Saunders CJ, Christensen M, Finger TE, Tizzano M. Cholinergic neurotransmission links solitary chemosensory cells to nasal inflammation. Proc Natl Acad Sci U S A. 2014;111:6075-80

76. Braham H, Cooper S, Anderson C, Tizzano M, Kingdom T, Finger T, et al. Solitary chemosensory cells and bitter taste receptor signaling in human sinonasal mucosa. Int Forum Allergy Rhinol. 2013;3:450-7.

77. Osculati F, Castellucci M, Cinti S, Zancanaro C. The solitary chemosensory cells and the diffuse chemosensory system of the airway. Eur J Histochem. 2007;51(Suppl 1):65-72.

78. Zhang Y, Hoon MA, Chandrashekar J, Mueller KL, Cook B, Wu D, et al. Coding of sweet, bitter, and umami tastes: different receptor cells sharing similar signaling pathways. Cell. 2003;112:293-301.

79. Iwata S, Yoshida R, Ninomiya Y. Taste transductions in taste receptor cells: basic tastes and moreover. Curr Pharm Des. 2014;20:2684-92.

80. Lee RJ, Kofonow JM, Rosen PL, Siebert AP, Chen B, Doghramji L, et al. Bitter and sweet taste receptors regulate human upper respiratory innate immunity. J Clin Invest. 2014;124:1393-405.

81. Baker EH, George S, Gyi KM, Hodson M, Philips BJ, Baines D, et al. Hyperglycaemia and cystic fibrosis alter respiratory fluid glucose concentrations estimated by breath condensate. J Appl Physiol. 2007;102:1969-75.

82. Workman AD, Maina IW, Brooks SG, Kohanski MA, Cowart BJ, Mansfield C, et al. The role of quinine-responsive Taste receptor Family 2 in airway immune defense and chronic rhinosinusitis. Front Immunol. 2018;9:624.

83. Workman AD, Brooks SG, Kohanski MA, Blasetti MT, Cowart BJ, Mansfield C, et al. Bitter and sweet taste tests are reflective of disease status in chronic rhinosinusitis. J Allergy Clin Immunol Pract. 2018;6:1078-80.

84. Lee RJ, Hariri BM, McMahon DB, Chen B, Doghramjii L, Adappa ND, et al. Bacterial D-amino acids suppress sinonasal innate immunity through sweet taste receptors in solitary chemosensory cells. Science Signaling. 2018; 10(495):eaam7703.

85. Camarinha-Silva A, Wos-Oxley ML, Jáuregui R, Becker K, Pieper DH. Validating T-RFLP as a sensitive and high-throughput approach to assess bacterial diversity patterns in human anterior nares. FEMS Microbiol Ecol. 2011;79:98-108.

86. Wos-Oxley ML, Plumeier I, Von Eiff C, Taudien S, Platzer M, Vilchez-Vargas R, et al. A poke into the diversity and associations within human anterior nare microbial communities. ISME J. 2010;4:839-51. https://doi.org/10.1038/ismej. 2010.15. 
87. Charlson ES, Chen J, Custers-Allen R, Bittinger K, Li H, Sinha R, et al. Disordered microbial communities in the upper respiratory tract of cigarette smokers. PLoS One. 2010;5:1-10.

88. Wilson M. Microbial inhabitants of humans. Cambridge: Cambridge Univ. Press; 2005. https://doi.org/10.1186/1471-2180-9-259.

89. Camarinha-Silva A, Jáuregui R, Pieper DH, Wos-Oxley ML. The tempora dynamics of bacterial communities across human anterior nares. Environ Microbiol Rep. 2012;4:126-32.

90. Frayman KB, Armstrong DS, Grimwood K, Ranganathan SC. The airway microbiota in early cystic fibrosis lung disease. Pediatr Pulmonol. 2017;52: 1384-404.

91. Teo SM, Mok D, Pham K, Kusel M, Serralha M, Troy N, et al. The infant airway microbiome in health and disease impacts later asthma development. Cell Host Microbe. 2015;17:704-15. https://doi.org/10.1016/j.chom.2015.03.008.

92. Biesbroek G, Tsivtsivadze E, Sanders EAM, Montijn R, Veenhoven RH, Keijser $B J F$, et al. Early respiratory microbiota composition determines bacterial succession patterns and respiratory health in children. Am J Respir Crit Care Med. 2014;190:1283-92.

93. Biesbroek G, Bosch AATM, Wang X, Keijser BJF, Veenhoven RH, Sanders EAM, et al. The impact of breastfeeding on nasopharyngeal microbial communities in infants. Am J Respir Crit Care Med. 2014;190:298-308.

94. Von Linstow ML, Schønning K, Hoegh AM, Sevelsted A, Vissing NH, Bisgaard $H$. Neonatal airway colonization is associated with troublesome lung symptoms in infants. Am J Respir Crit Care Med. 2013;188:1041-2.

95. Moore H, Jacoby P, Taylor A, Harnett G, Bowman J. V Riley T, et al. The interaction between respiratory viruses and pathogenic bacteria in the upper respiratory tract of asymptomatic aboriginal and non-aboriginal children. Pediatr Infect Dis J. 2010;29:540-5.

96. van den Bergh MR, Biesbroek G, Rossen JWA, de Steenhuijsen Piters WAA, Bosch AATM, van Gils EJM, et al. Associations between pathogens in the upper respiratory tract of young children: interplay between viruses and bacteria. PLoS One. 2012;7:e47711. https://doi.org/10.1371/journal.pone. 0047711.

97. Vissing NH, Chawes BLK, Bisgaard H. Increased risk of pneumonia and bronchiolitis after bacterial colonization of the airways as neonates. Am J Respir Crit Care Med. 2013;188:1246-52.

98. Camarinha-Silva A, Jáuregui R, Chaves-Moreno D, Oxley APA, Schaumburg F, Becker $\mathrm{K}$, et al. Comparing the anterior nare bacterial community of two discrete human populations using Illumina amplicon sequencing. Environ Microbiol. 2014;16:2939-52

99. Zhou Y, Gao H, Mihindukulasuriya KA, Rosa PSL, Wylie KM, Vishnivetskaya T, et al. Biogeography of the ecosystems of the healthy human body. Genome Biol. 2013;14:R1. https://doi.org/10.1186/gb-2013-14-1-r1.

100. Oh J, Byrd AL, Deming C, Conlan S, Program NCS, Kong HH, et al. Biogeography and individuality shape function in the human skin metagenome. Nature. 2014;514:59-64. https://doi.org/10.1038/nature13786.

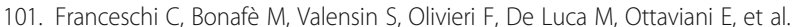
Inflamm-aging: an evolutionary perspective on immunosenescence. Ann N Y Acad Sci. 2006;908:244-54. https://doi.org/10.1111/j.1749-6632.2000. tb06651.x.

102. Stämpfli MR, Anderson GP. How cigarette smoke skews immune responses to promote infection, lung disease and cancer. Nat Rev Immunol. 2009;9: 377 EP.

103. Macgregor I. Effects of smoking on oral ecology. A review of the literature. Clin Prev Dent. 1989;11:3-7.

104. Yu G, Phillips S, Gail MH, Goedert JJ, Humphrys MS, Ravel J, et al. The effect of cigarette smoking on the oral and nasal microbiota. Microbiome. 2017;5: 1-6. https://doi.org/10.1186/s40168-016-0226-6.

105. Mason R. Biology of alveolar type II cells. Respirology. 2006;11(Suppl: S1):2-5.

106. Ratner AJ, Lysenko ES, Paul MN, Weiser JN. Synergistic proinflammatory responses induced by polymicrobial colonization of epithelial surfaces. Proc Natl Acad Sci U S A. 2005;102:3429-34. https://doi.org/10.1073/pnas. 0500599102

107. Phipps JC, Aronoff DM, Curtis JL, Goel D, O'Brien E, Mancuso P. Cigarette smoke exposure impairs pulmonary bacterial clearance and alveolar macrophage complement-mediated phagocytosis of Streptococcus pneumoniae. Infect Immun. 2010;78:1214-20.

108. Castranova V, Huffman LJ, Judy DJ, Bylander JE, Lapp LN, Weber SL, et al. Enhancement of nitric oxide production by pulmonary cells following silica exposure. Environ Health Perspect. 1998;106(Suppl 5):1165-9. https://doi. org/10.1289/ehp.98106s51165.
109. Chaudhuri N, Sabroe I. Basic science of the innate immune system and the lung. Paediatr Respir Rev. 2008;9:236-42. https://doi.org/10.1016/j.prrv.2008. 03.002.

110. Bagaitkar J, Demuth DR, Daep CA, Renaud DE, Pierce DL, Scott DA. Tobacco upregulates $P$. gingivalis fimbrial proteins which induce TLR2 hyposensitivity. PLoS One. 2010;5:e9323.

111. Garmendia J, Morey P, Bengoechea JA. Impact of cigarette smoke exposure on host-bacterial pathogen interactions. Eur Respir J. 2012;39:467-77.

112. Goldstein-Daruech N, Cope EK, Zhao K-Q, Vukovic K, Kofonow JM, Doghramji $L$, et al. Tobacco smoke mediated induction of sinonasal microbial biofilms. PLoS One. 2011;6:e15700.

113. Kulkarni R, Antala S, Wang A, Amaral FE, Rampersaud R, LaRussa SJ, et al. Cigarette smoke increases Staphylococcus aureus biofilm formation via oxidative stress. Infect Immun. 2012;80:3804-11. https://doi.org/10.1128/IAI. 00689-12

114. McEachern EK, Hwang JH, Sladewski KM, Nicatia S, Dewitz C, Mathew DP, et al. Analysis of the effects of cigarette smoke on staphylococcal virulence phenotypes. Infect Immun. 2015;83:2443-52.

115. Mutepe ND, Cockeran R, Steel HC, Theron AJ, Mitchell TJ, Feldman C, et al. Effects of cigarette smoke condensate on pneumococcal biofilm formation and pneumolysin. Eur Respir J. 2013:41:392. https://doi.org/10.1183/ 09031936.00213211.

116. Shen P, Whelan FJ, Schenck LP, McGrath JJC, Vanderstocken G, Bowdish $D M E$, et al. Streptococcus pneumoniae colonization is required to alter the nasal microbiota in cigarette smokeexposed mice. Infect Immun. 2017:85:1-14.

117. Brook I, Gober AE. Recovery of potential pathogens in the nasopharynx of healthy and otitis media-prone children and their smoking and nonsmoking parents. Ann Otol Rhinol Laryngol. 2005;117:727-30.

118. Greenberg D, Givon-Lavi N, Broides A, Blancovich I, Peled N, Dagan R. The contribution of smoking and exposure to tobacco smoke to Streptococcus pneumoniae and Haemophilus influenzae carriage in children and their mothers. Clin Infect Dis. 2006;42:897-903. https://doi.org/10.1086/500935.

119. Sapkota AR, Berger S, Vogel TM. Human pathogens abundant in the bacterial metagenome of cigarettes. Environ Health Perspect. 2009;118: 351-6.

120. Brook I, Gober AE. Effect of smoking cessation on the microbial flora. Arch Otolaryngol Head Neck Surg. 2007;133:135-8. https://doi.org/10.1001/ archotol.133.2.135

121. García-Rodríguez J, Fresnadillo M. Dynamics of nasopharyngeal clonization by potential respiratory pathogens. J Antimicrob Chemother. 2002;50(Suppl S2):59-73.

122. Iles K, Poplawski NK, Couper RT. Passive exposure to tobacco smoke and bacterial meningitis in children. J Paediatr Child Health. 2001;37:388-91.

123. Morris $B$, Henneberger $R$, Huber $H$, Moissl-Eichinger C. Microbial syntrophy: interaction for the common good. FEMS Microbiol Rev. 2013;37:384-406.

124. Krismer B, Liebeke M, Janek D, Nega M, Rautenberg M, Hornig G, et al. Nutrient limitation governs Staphylococcus aureus metabolism and niche adaptation in the human nose. PLOS Pathog. 2014;10:e1003862.

125. Ferraris R, Yasharpour S, Lloyd K, Mirzayan R, Diamond J. Luminal glucose concentrations in the gut under normal conditions. Am J Physiol. 1990;259: G822-37.

126. Lorin M, Gaerlan P, Mandel I. Quantitative composition of nasal secretions in normal subjects. J Lab Clin Med. 1972;80:275-81.

127. Vanthanouvong $\vee$, Roomans $G$. Methods for determining the composition of nasal fluid by X-ray microanalysis. Microsc Res Tech. 2004;63:122-8.

128. Winkelmann G. Microbial siderophore-mediated transport. Biochem Soc Trans. 2002;30:691-6.

129. Ramsey MM, Freire MO, Gabrilska RA, Rumbaugh KP, Lemon KP. Staphylococcus aureus shifts toward commensalism in response to Corynebacterium species. Front Micobiology. 2016;7:1-15.

130. Stubbendieck RM, May DS, Chevrette MG, Temkin MI, Wendt-Pienkowski E, Cagnazzo J, et al. Competition among nasal bacteria suggests a role for siderophore-mediated interactions in shaping the human nasal microbiota. Am Soc Microbiol. 2019;85(10):e02406-18.

131. Bomar L, Brugger SD, Yost BH, Davies SS, Lemon P. Corynebacterium accolens releases antipneumococcal free fatty acids from human nostril and skin surface triacylglycerols. MBio. 2016;7:1-13.

132. Wollenberg MS, Claesen J, Escapa IF, Aldridge KL, Fischbach MA, Lemon P. Propionibacterium -produced coproporphyrin III induces Staphylococcus aureus aggregation and biofilm formation. MBio. 2014;5:1-10. 
133. Lemon KP, Klepac-Ceraj V, Schiffer HK, Brodie EL, Lynch SV, Kolter R. Comparative analyses of the bacterial microbiota of the human nostril and oropharynx. MBio. 2010;1:4-6.

134. Frank DN, Feazel LM, Bessesen MT, Price CS, Janoff EN, Pace NR. The human nasal microbiota and Staphylococcus aureus carriage. PLoS One. 2010;5: e10598.

135. von Eiff C, Becker K, Machka K, Stammer H, Peters G. Nasal carriage as a source of Staphylococcus aureus bacteremia. N Engl J Med. 2001:344:11-6.

136. Wertheim HF, Vos MC, Ott A, van Belkum A, Voss A, Kluytmans JA, et al. Risk and outcome of nosocomial Staphylococcus aureus bacteraemia in nasal carriers versus non-carriers. Lancet. 2004;364:703-5.

137. Consortium HM. Structure, function and diversity of the healthy human microbiome. Nature. 2012;486:207-14. https://doi.org/10.1038/nature11234.

138. Grice EA, Kong HH, Conlan S, Deming CB, Davis J, Young AC, et al. Topographical and temporal diversity of the human skin microbiome. Science. 2009;324:1190-2. https://doi.org/10.1126/science.1171700.

139. Kuehnert M, Kruszon-Moran D, Hill H, McQuillan G, McAllister S, Fosheim G, et al. Prevalence of Staphylococcus aureus nasal colonization in the United States, 2001-2002. J Infect Dis. 2006;193:172-9.

140. Gorwitz R, Kruszon-Moran D, McAllister S, MCQuillan G, McDougal L, Fosheim $\mathrm{G}$, et al. Changes in the prevalence of nasal colonization with Staphylococcus aureus in the United States, 2001-2004. J Infect Dis. 2008, 197:1226-34.

141. Barbara G, Stanghellini V, Brandi G, Cremon C, Di Nardo G, De Giorgio R, et al. Interactions between commensal bacteria and gut sensorimotor function in health and disease. Am J Gastroenterol. 2005;100:2560-8.

142. Zipperer A, Konnerth MC, Laux C, Berscheid A, Janek D, Weidenmaier C, et al. Human commensals producing a novel antibiotic impair pathogen colonization. Nature. 2016;535:511-6. https://doi.org/10.1038/nature18634.

143. Janek D, Zipperer A, Kulik A, Krismer B, Peschel A. High frequency and diversity of antimicrobial activities produced by nasal Staphylococcus strains against bacterial competitors. PLOS Pathog. 2016;12:e1005812.

144. Novick R, Geisinger E. Quorum sensing in staphylococci. Annu Rev Genet. 2008:42:541-64

145. Thoendel M, Horswill A. Identification of Staphylococcus aureus AgrD residues required for autoinducing peptide biosynthesis. J Biol Chem. 2009; 284:21828-38

146. Lindsay JA, Riley TV, Meel BJ. Staphylococcus aureus but not Staphylococcus epidermidis can acquire iron from transferrin. Microbiology. 1995;141:197-203.

147. Schaller M, Loewenstein M, Borelli C, Jacob K, Vogeser M, Burgdorf W, et al. Induction of a chemoattractive proinflammatory cytokine response after stimulation of keratinocytes with Propionibacterium acnes and coproporphyrin III. Br J Dermatol. 2005;153:66-71.

148. Borelli C, Merk K, Schaller M, Jacob K, Vogeser M, Weindl G, et al. In vivo porphyrin production by $P$. acnes in untreated acne patients and its modulation by acne treatment. Acta Derm Venereol. 2006;86:316-9.

149. Bogaert D, De Groot R, Hermans PWM. Streptococcus pneumoniae colonisation: the key to pneumococcal disease. Lancet Infect Dis. 2004;4: 144-54.

150. Nakatsuji T, Kao MC, Zhang L, Zouboulis CC, Gallo RL, Huang C-M. Sebum free fatty acids enhance the innate immune defense of human sebocytes by upregulating b-defensin-2 expression. J Invest Dermatol. 2010;130:98594. https://doi.org/10.1038/jid.2009.384.

151. Lee H, Andalibi A, Webster P, Moon S, Teufert K, Kang S, et al. Antimicrobial activity of innate immune molecules against Streptococcus pneumoniae, Moraxella catarrhalis and nontypeable. BMC Infect Dis. 2004:4:1-12.

152. Mahnert A, Blohs M, Pausan M-R, Moissl-Eichinger $C$. The human archaeome: methodological pitfalls and knowledge gaps. Emerg Top Life Sci. 2018;2:469-82. https://doi.org/10.1042/ETLS20180037.

153. Pausan MR, Csorba C, Singer G, Till H, Schoepf V, Santigli E, et al. Measuring the archaeome: detection and quantification of archaea signatures in the human body. bioRxiv. 2018:334748. https://doi.org/10.1101/334748.

154. Sogodogo E, Fellag M, Loukil A, Nkamga V, Michel J, Dessi P, et al. Nine cases of methanogenic archaea in refractory sinusitis, an emerging clinical entity. Front Public Heal. 2019;7:38.

155. Cui L, Morris A, Ghedin E. The human mycobiome in health and disease. Genome Med. 2013;5:63. https://doi.org/10.1186/gm467.

156. Korten I, Mika M, Klenja S, Kieninger E, Mack I, Barbani MT, et al. Interactions of respiratory viruses and the nasal microbiota during the first year of life in healthy infants. mSphere. 2016;1:e00312-6. https://doi.org/10.1128/mSphere. 00312-16.
157. Jung WH, Croll D, Cho JH, Kim YR, Lee YW. Analysis of the nasal vestibule mycobiome in patients with allergic rhinitis. Mycoses. 2015;58:167-72. https://doi.org/10.1111/myc.12296.

158. Popgeorgiev N, Temmam S, Raoult D, Desnues C. Describing the silent human virome with an emphasis on giant viruses. Intervirology. 2013;56: 395-412. https://doi.org/10.1159/000354561.

159. Van der Schans CP. Bronchial mucus transport. Respir Care. 2007;52:1150-6; discussion 1156-8. https://doi.org/10.1016/0952-8180(93)90100-S.

160. Heintz-Buschart A, Pandey U, Wicke T, Sixel-Döring F, Janzen A, Sittig-

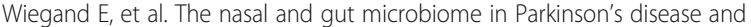
idiopathic rapid eye movement sleep behavior disorder. Mov Disord. 2017; 33:88-98.

161. Pail G, Huf W, Pjrek E, Winkler D, Willeit M, Praschak-Rieder N, et al. Brightlight therapy in the treatment of mood disorders. Neuropsychobiology. 2011;64:152-62. https://www.karger.com/. https://doi.org/10.1159/ 000328950

162. Hoggard M, Biswas K, Zoing M, Wagner Mackenzie B, Taylor MW, Douglas RG. Evidence of microbiota dysbiosis in chronic rhinosinusitis. Int Forum Allergy Rhinol. 2017;7:230-9. https://doi.org/10.1002/alr.21871.

163. Fokkens WJ, Lund VJ, Mullol J, Bachert C, Alobid I, Baroody F, et al. EPOS 2012: European position paper on rhinosinusitis and nasal polyps 2012. A summary for otorhinolaryngologists. Rhinol J. 2012;50:1-12. https://doi.org/ 10.4193/Rhino50E2.

164. Foreman A, Jervis-Bardy J, Wormald P-J. Do biofilms contribute to the initiation and recalcitrance of chronic rhinosinusitis? Laryngoscope. 2011; 121:1085-91. https://doi.org/10.1002/lary.21438.

165. Shin S, Ponikau J, Sherris D, Congdon D, Frigas E, Homburger H, et al. Chronic rhinosinusitis: an enhanced immune response to ubiquitous airborne fungi. J Allergy Clin Immunol. 2004;114:1369-75.

166. Bachert C, Gevaert P, van Cauwenberge P. Staphylococcus aureus enterotoxins: a key in airway disease? Allergy. 2002;57:480-7.

167. Mahdavinia M, Keshavarzian A, Tobin MC, Landay A, Schleimer RP. A comprehensive review of the nasal microbiome in chronic rhinosinusitis (CRS). Clin Exp Allergy. 2016:46:21-41. https://doi.org/10.1111/cea.12666.

168. Cope EK, Goldberg AN, Pletcher SD, Lynch SV. Compositionally and functionally distinct sinus microbiota in chronic rhinosinusitis patients have immunological and clinically divergent consequences. Microbiome. 2017;5:53. https://doi.org/10.1186/s40168-017-0266-6.

169. Choi E-B, Hong S-W, Kim D-K, Jeon SG, Kim K-R, Cho S-H, et al. Decreased diversity of nasal microbiota and their secreted extracellular vesicles in patients with chronic rhinosinusitis based on a metagenomic analysis. Allergy. 2014;69:517-26. https://doi.org/10.1111/all.12374.

170. Wagner Mackenzie B, Waite DW, Hoggard M, Douglas RG, Taylor MW, Biswas K. Bacterial community collapse: a meta-analysis of the sinonasal microbiota in chronic rhinosinusitis. Environ Microbiol. 2017;19:381-92. https://doi.org/10.1111/1462-2920.13632.

171. Psaltis AJ, Wormald P-J. Therapy of sinonasal microbiome in CRS: a critical approach. Curr Allergy Asthma Rep. 2017;17:59. https://doi.org/10.1007/ s11882-017-0726-x.

172. Dlugaszewska J, Leszczynska M, Lenkowski M, Tatarska A, Pastusiak T, Szyfter W. The pathophysiological role of bacterial biofilms in chronic sinusitis. Eur Arch Otorhinolaryngol. 2016;273:1989-94. https://doi.org/10.1007/s00405015-3650-5

173. Stephenson M-F, Mfuna L, Dowd SE, Wolcott RD, Barbeau J, Poisson M, et al. Molecular characterization of the polymicrobial flora in chronic rhinosinusitis. J Otolaryngol Head Neck Surg. 2010;39:182-7 http://www ncbi.nlm.nih.gov/pubmed/20211106. Accessed 16 Oct 2018.

174. Ramakrishnan VR, Hauser LJ, Feazel LM, Ir D, Robertson CE, Frank DN. Sinus microbiota varies among chronic rhinosinusitis phenotypes and predicts surgical outcome. J Allergy Clin Immunol. 2015;136:334-42.e1. https://doi. org/10.1016/J.JACI.2015.02.008.

175. Hirschberg A, Kiss M, Kadocsa E, Polyanka H, Szabo K, Razga Z, et al. Different activations of toll-like receptors and antimicrobial peptides in chronic rhinosinusitis with or without nasal polyposis. Eur Arch Otorhinolaryngol. 2016. 273:1779-88. https://doi.org/10.1007/s00405-015-3816-1.

176. Aurora R, Chatterjee D, Hentzleman J, Prasad G, Sindwani R, Sanford T. Contrasting the microbiomes from healthy volunteers and patients with chronic rhinosinusitis. JAMA Otolaryngol Neck Surg. 2013;139:1328. https:// doi.org/10.1001/jamaoto.2013.5465.

177. Chalermwatanachai T, Vilchez-Vargas $R$, Holtappels $G$, Lacoere $T$, Jáuregui $R$, Kerckhof F-M, et al. Chronic rhinosinusitis with nasal polyps is characterized 
by dysbacteriosis of the nasal microbiota. Sci Rep. 2018;8:7926. https://doi. org/10.1038/s41598-018-26327-2.

178. Brook I. The role of anaerobic bacteria in sinusitis. Anaerobe. 2006;12:5-12. https://doi.org/10.1016/J.ANAEROBE.2005.08.002.

179. Kuhar HN, Tajudeen BA, Mahdavinia M, Heilingoetter A, Ganti A, Gattuso P, et al. Relative abundance of nasal microbiota in chronic rhinosinusitis by structured histopathology. Int Forum Allergy Rhinol. 2018. https://doi.org/10. 1002/alr.22192.

180. Naraghi M, Deroee AF, Ebrahimkhani M, Kiani S, Dehpour A. Nitric oxide: a new concept in chronic sinusitis pathogenesis B. Am J Otolaryngol. 2007;28: 334-7.

181. Carey RM, Workman AD, Hatten KM, Siebert AP, Brooks SG, Chen B, et al. Denatonium-induced sinonasal bacterial killing may play a role in chronic rhinosinusitis outcomes. Int Forum Allergy Rhinol. 2017;7:699-704.

182. Adappa ND, Truesdale CM, Workman AD, Doghramji L, Mansfield C, Kennedy DW, et al. Correlation of T2R38 taste phenotype and in vitro biofilm formation from nonpolypoid chronic rhinosinusitis patients. Int Forum Allergy Rhinol. 2017;6:783-91.

183. Bell JS, Spencer JI, Yates RL, Yee SA, Jacobs BM, DeLuca GC. Invited review: From nose to gut - the role of the microbiome in neurological disease. Neuropathol Appl Neurobiol. 2018:nan.12520. https://doi.org/10.1111/nan. 12520.

184. François A, Grebert D, Rhimi M, Mariadassou M, Naudon L, Rabot S, et al. Olfactory epithelium changes in germfree mice. Sci Rep. 2016;6:24687. https://doi.org/10.1038/srep24687.

185. Braak H, Del Tredici K, Rüb U, Vos RAl, Jansen Steur ENH, Braak E. Staging of brain pathology related to sporadic Parkinson's disease. Neurobiol Aging. 2003;24:197-211. https://doi.org/10.1016/S0197-4580(02)00065-9.

186. Braak H, Vos RAl, Bohl J, Del Tredici K. Gastric a-synuclein immunoreactive inclusions in Meissner's and Auerbach's plexuses in cases staged for Parkinson's disease-related brain pathology. Neurosci Lett. 2006;396:67-72. https://doi.org/10.1016/j.neulet.2005.11.012.

187. Haehner A, Boesveldt S, Berendse HW, Mackay-Sim A, Fleischmann J, Silburn PA, et al. Prevalence of smell loss in Parkinson's disease - a multicenter study. Park Relat Disord. 2009;15:490-4. https://doi.org/10.1016/j.parkreldis. 2008.12.005.

188. Béraud D, Maguire-Zeiss KA. Misfolded a-synuclein and toll-like receptors: therapeutic targets for Parkinson's disease. Parkinsonism Relat Disord. 2012; 18(Supplement 1):17-20. https://doi.org/10.1016/S1353-8020(11)70008-6.

189. Friedland RP. Mechanisms of molecular mimicry involving the microbiota in neurodegeneration. J Alzheimer's Dis. 2015;45:349-62.

190. Khan F, Oloketuyi SF. A future perspective on neurodegenerative diseases: nasopharyngeal and gut microbiota. J Appl Microbiol. 2016;122:306-20.

191. Mulak A, Bonaz B. Brain-gut-microbiota axis in Parkinson's disease. World J Gastroenterol. 2015;21:10609-20. https://doi.org/10.3748/wjg.v21.i37.10609.

192. Pereira PAB, Aho VTE, Paulin L, Pekkonen E, Auvinen P, Scheperjans F. Oral and nasal microbiota in Parkinson's disease. Park Relat Disord. 2017;38:61-7. https://doi.org/10.1016/j.parkreldis.2017.02.026.

193. Hawkes CH, Del Tredici K, Braak H. Parkinson's disease: a dual-hit hypothesis. Neuropathol Appl Neurobiol. 2007;33:599-614.

194. Boutin S, Graeber SY, Weitnauer M, Panitz J, Stahl M, Clausznitzer D, et al. Comparison of microbiomes from different niches of upper and lower airways in children and adolescents with cystic fibrosis. PLoS One. 2015;10: 1-19. https://doi.org/10.1371/journal.pone.0116029.

195. Prevaes SMPJ, De Steenhuiisen Piters WAA, De Winter-De Groot KM, Janssens HM, Tramper-Stranders GA, Chu MLJN, et al. Concordance between upper and lower airway microbiota in infants with cystic fibrosis. Eur Respir J. 2017;49. https://doi.org/10.1183/13993003.02235-2016.

196. Boyle M. Adult cystic fibrosis. J Am Med Assoc. 2007;298:1787-93.

197. Fodor AA, Klem ER, Gilpin DF, Elborn JS, Boucher RC, Tunney MM, et al. The adult cystic fibrosis airway microbiota is stable over time and infection type, and highly resilient to antibiotic treatment of exacerbations. PLoS One. 2012;7:e45001.

198. Parkins MD, Floto RA. Emerging bacterial pathogens and changing concepts of bacterial pathogenesis in cystic fibrosis. J Cyst Fibros. 2015;14: 293-304. https://doi.org/10.1016/j.jcf.2015.03.012.

199. Tracy M, Cogen J, Hoffman LR. The pediatric microbiome and the lung. Curr Opin Pediatr. 2015;27:348-55. https://doi.org/10.1097/MOP. 0000000000000212 .

200. Whiteson KL, Bailey B, Bergkessel M, Conrad D, Delhaes L, Felts B, et al. The upper respiratory tract as a microbial source for pulmonary infections in cystic fibrosis. Parallels from island biogeography. Am J Respir Crit Care Med. 2014;189:1309-15. https://doi.org/10.1164/rccm.201312-2129PP.

201. Burns JL, Gibson RL, McNamara S, Yim D, Emerson J, Rosenfeld M, et al. Longitudinal assessment of Pseudomonas aeruginosa in young children with cystic fibrosis. J Infect Dis. 2001;183:444-52.

202. Jelsbak L, Johansen HK, Frost A-L, Thøgersen R, Thomsen LE, Ciofu O, et al. Molecular epidemiology and dynamics of Pseudomonas aeruginosa populations in lungs of cystic fibrosis patients. Infect Immun. 2007;75:221424. https://doi.org/10.1128/IAl.01282-06.

203. Goss CH, Muhlebach MS. Review: Staphylococcus aureus and MRSA in cystic fibrosis. J Cyst Fibros. 2011;10:298-306. https://doi.org/10.1016/j.jff.2011.06.002.

204. Tiddens HAWM, Stick SM, Davis S. Multi-modality monitoring of cystic fibrosis lung disease: the role of chest computed tomography. Paediatr Respir Rev. 2014;15:92-7. https://doi.org/10.1016/j.prrv.2013.05.003.

205. Mellert TK, Getchell ML, Sparks L, Getchell TV. Characterization of the immune barrier in human olfactory mucosa. Otolaryngol Head Neck Surg. 1992;106:181-8.

206. Kimmelman CP. Clinical review of olfaction. Am J Otolaryngol. 1993;14:22739. https://doi.org/10.1016/0196-0709(93)90065-F.

207. Grenham S, Clarke G, Cryan JF, Dinan TG. Brain-gut-microbe communication in health and disease. Front Physiol. 2011;2:94. https://doi.org/10.3389/fphys. 2011.00094

208. Hughes DT, Sperandio V. Inter-kingdom signalling: communication between bacteria and their hosts. Nat Rev Microbiol. 2008;6:111-20. https://doi.org/ 10.1038/nrmicro1836.

209. Wilson MT, Hamilos DL. The nasal and sinus microbiome in health and disease. Curr Allergy Asthma Rep. 2014;14:485.

210. Wegener B-A, Croy I, Hähner A, Hummel T. Olfactory training with older people. Int J Geriatr Psychiatry. 2018;33:212-20. https://doi.org/10.1002/gps. 4725.

211. Pekala K, Chandra RK, Turner JH. Efficacy of olfactory training in patients with olfactory loss: a systematic review and meta-analysis. Int Forum Allergy Rhinol. 2016;6:299-307. https://doi.org/10.1002/alr.21669.

212. Liu CM, Price LB, Hungate BA, Abraham AG, Larsen LA, Christensen K, et al. Staphylococcus aureus and the ecology of the nasal microbiome. Sci Adv. 2015;1. https://doi.org/10.1126/sciadv.1400216.

213. Ramakrishnan VR, Hauser LJ, Frank DN. The sinonasal bacterial microbiome in health and disease. Curr Opin Otolaryngol Head Neck Surg. 2016;24:20-5. https://doi.org/10.1097/MO0.0000000000000221.

214. Bosch AATM, Levin E, van Houten MA, Hasrat R, Kalkman G, Biesbroek G, et al. Development of upper respiratory tract microbiota in infancy is affected by mode of delivery. EBioMedicine. 2016;9:336-45. https://doi.org/ 10.1016/j.ebiom.2016.05.031 M4 - Citavi.

215. Lécuyer $H$, Audibert J, Bobigny A, Eckert $C$, Jannière-Nartey $C$, Buu-Hoï $A$, et al. Dolosigranulum pigrum causing nosocomial pneumonia and septicemia. J Clin Microbiol. 2007;45:3474-5. https://doi.org/10.1128/JCM. 01373-07.

216. Boesveldt S, Postma EM, Boak D, Welge-Luessen A, Schöpf V, Mainland JD, et al. Anosmia - a clinical review. Chem Senses. 2017:42:513-23.

217. Hummel T, Sekinger B, Wolf SR, Pauli E, Kobal G. "Sniffin" Sticks': Olfactory performance assessed by the combined testing of odor identification, odor discrimination and olfactory threshold. 1997. https://academic.oup.com/ chemse/article-abstract/22/1/39/383479. Accessed 11 Jan 2019.

218. Jain R, Hoggard M, Biswas K, Zoing M, Jiang Y, Douglas R. Changes in the bacterial microbiome of patients with chronic rhinosinusitis after endoscopic sinus surgery. Int Forum Allergy Rhinol. 2017;7:7-15. https://doi. org/10.1002/alr.21849.

219. Kern RC. Candidate's Thesis: Chronic sinusitis and anosmia: pathologic changes in the olfactory mucosa. Laryngoscope. 2009;110:1071-7.

220. Hornung DE. Nasal anatomy and the sense of smell. Adv Otorhinolaryngol. 2006;63:1-22.

221. Wiley. Bergey's Manual of Systematics of Archaea and Bacteria. 2015.

222. Mygind N, Nielsen LP, Hoffmann H-J, Shukla A, Blumberga G, Dahl R, et al. Mode of action of intranasal corticosteroids. J Allergy Clin Immunol. 2001; 108:S16-25. https://doi.org/10.1067/MAl.2001.115561.

223. Rogers GB, Shaw D, Marsh RL, Carroll MP, Serisier DJ, Bruce KD. Respiratory microbiota: addressing clinical questions, informing clinical practice. Thorax. 2015;70:74-81. https://doi.org/10.1136/thoraxjnl-2014-205826.

224. Wang L-M, Qiao X-L, Ai L, Zhai J-J, Wang X-X. Isolation of antimicrobial resistant bacteria in upper respiratory tract infections of patients. 3. Biotech. 2016;6:166. https://doi.org/10.1007/s13205-016-0473-z. 
225. Perl TM, Cullen JJ, Wenzel RP, Zimmerman MB, Pfaller MA, Sheppard D, et al. Intranasal mupirocin to prevent postoperative Staphylococcus aureus infections. N Engl J Med. 2002;346:1871-7. https://doi.org/10.1056/ NEJMoa003069.

226. Bode LGM, Kluytmans JAJW, Wertheim HFL, Bogaers D, VandenbrouckeGrauls CMJE, Roosendaal R, et al. Preventing surgical-site infections in nasal carriers of Staphylococcus aureus. N Engl J Med. 2010;362:9-17. https://doi. org/10.1056/NEJMoa0808939.

227. Choi K, Jang DW, Ellison MD, Frank-Ito DO. Characterizing airflow profile in the postoperative maxillary sinus by using computational fluid dynamics modeling: a pilot study. Am J Rhinol Allergy. 2016;30:29-36. https://doi.org/ 10.2500/ajra.2016.30.4266.

228. Kennedy DW. Prognostic factors, outcomes and staging in ethmoid sinus surgery. Laryngoscope. 1992;102(12 Pt 2 Suppl 57):1-18 http://www.ncbi. nIm.nih.gov/pubmed/1453856. Accessed 9 Oct 2018.

229. Hauser $\sqcup$, Ir D, Kingdom TT, Robertson CE, Frank DN, Ramakrishnan VR. Investigation of bacterial repopulation after sinus surgery and perioperative antibiotics. Int Forum Allergy Rhinol. 2016;6:34-40. https://doi.org/10.1002/ alr.21630.

230. Jervis-Bardy J, Foreman A, Field J, Wormald PJ. Impaired mucosal healing and infection associated with Staphylococcus aureus after endoscopic sinus surgery. Am J Rhinol Allergy. 2009;23:549-52. https://doi.org/10.2500/ajra. 2009.23.3366

231. Tan NC-W, Foreman A, Jardeleza C, Douglas R, Tran H, Wormald PJ. The multiplicity of Staphylococcus aureus in chronic rhinosinusitis: correlating surface biofilm and intracellular residence. Laryngoscope. 2012;122:1655-60. https://doi.org/10.1002/lary.23317.

232. Plouin-Gaudon I, Clement S, Huggler E, Chaponnier C, François P, Lew D, et al. Intracellular residency is frequently associated with recurrent Staphylococcus aureus rhinosinusitis. Rhinology. 2006;44:249-54 http://www. ncbi.nlm.nih.gov/pubmed/17216740. Accessed 9 Oct 2018.

233. Jervis-Bardy J, Foreman A, Boase S, Valentine R, Wormald P-J. What is the origin of Staphylococcus aureus in the early postoperative sinonasal cavity? Int Forum Allergy Rhinol. 2011;1:308-12. https://doi.org/10.1002/alr.20050.

234. Bhattacharyya N, Gopal HV, Lee KH. Bacterial infection after endoscopic sinus surgery: a controlled prospective study. Laryngoscope. 2004;114:765-7. https://doi.org/10.1097/00005537-200404000-00032.

235. Rama S, Ballentine R, Hymes A. Science of breath: a practical guide. Honesdale: Himalayan Institute Press; 1998.

236. Bastier P-L, Lechot A, Bordenave L, Durand M, de Gabory L. Nasal irrigation: from empiricism to evidence-based medicine. A review. Eur Ann Otorhinolaryngol Head Neck Dis. 2015;132:281-5. https://doi.org/10.1016/J. ANORL.2015.08.001.

237. Georgitis JW. Nasal hyperthermia and simple irrigation for perennial rhinitis: changes in inflammatory mediators. Chest J. 1994;106:1487-92. https://doi. org/10.1378/CHEST.106.5.1487.

238. Hauser $L$, Ir D, Kingdom TT, Robertson CE, Frank DN, Ramakrishnan VR. Evaluation of bacterial transmission to the paranasal sinuses through sinus irrigation. Int Forum Allergy Rhinol. 2016;6:800-6. https://doi.org/10.1002/alr. 21755.

239. Singhal D, Foreman A, Bardy J-J, Wormald P-J. Staphylococcus aureus biofilms. Laryngoscope. 2011;121:1578-83. https://doi.org/10.1002/lary. 21805.

240. Psaltis AJ, Foreman A, Wormald P-J, Schlosser RJ. Contamination of sinus irrigation devices: a review of the evidence and clinical relevance. Am J Rhinol Allergy. 2012;26:201-3. https://doi.org/10.2500/ajra.2012.26.3747.

241. Tichenor WS, Thurlow J, McNulty S, Brown-Elliott BA, Wallace RJ, Falkinham JO. Nontuberculous mycobacteria in household plumbing as possible cause of chronic rhinosinusitis. Emerg Infect Dis. 2012;18:1612-7. https://doi.org/ 10.3201/eid1810.120164.

242. Yoder JS, Straif-Bourgeois S, Roy SL, Moore TA, Visvesvara GS, Ratard RC, et al. Primary amebic meningoencephalitis deaths associated with sinus irrigation using contaminated tap water. Clin Infect Dis. 2012;55:e79-85. https://doi.org/10.1093/cid/cis626.

243. Georas SN, Rezaee F. Epithelial barrier function: at the frontline of asthma immunology and allergic airway inflammation. J Allergy Clin Immunol. 2014; 134:509-20.

244. Soyka MB, Wawrzyniak P, Eiwegger T, Holzmann D, Treis A, Wanke $K$, et al. Defective epithelial barrier in chronic rhinosinusitis: the regulation of tight junctions by IFN- $\mathrm{g}$ and IL-4. Am Acad Allergy Asthma Immunol. 2012;130: 1087-96.
245. Hill C, Guarner F, Reid G, Gibson GR, Merenstein DJ, Pot B, et al. The International Scientific Association for Probiotics and Prebiotics consensus statement on the scope and appropriate use of the term probiotic. Nat Rev Gastroenterol Hepatol. 2014;11:506-14.

246. Martens K, Pugin B, De Boeck I, Spacova I, Steelant B, Seys SF, et al. Probiotics for the airways: potential to improve epithelial and immune homeostasis. Allergy. 2018. https://doi.org/10.1111/all.13495.

247. Cope EK, Lynch SV. Novel microbiome-based therapeutics for chronic rhinosinusitis. Curr Allergy Asthma Rep. 2015;15:504.

248. Mack D, Ahrne S, Hyde L, Wei S, Hollingsworth M. Extracellular MUC3 mucin secretion follows adherence of Lactobacillus strains to intestinal epithelial cells in vitro. Gut. 2003;52:827-33.

249. Rao R, Samak G. Protection and restitution of gut barrier by probiotics: nutritional and clinical implications. Curr Nutr Food Sci. 2013;9:99-107.

250. Sagar S, Vos AP, Morgan ME, Garssen J, Georgiou NA, Boon L, et al. The combination of Bifidobacterium breve with non-digestible oligosaccharides suppresses airway inflammation in a murine model for chronic asthma. Biochim Biophys Acta Mol Basis Dis. 1842;2014:573-83. https://doi.org/10. 1016/j.bbadis.2014.01.005.

251. Blaser M, Bork P, Fraser C, Knight R, Wang J. The microbiome explored: recent insights and future challenges. Nat Rev Microbiol. 2013;11:213-7.

252. Zheng J, Gänzle MG, Lin XB, Ruan L, Sun M. Diversity and dynamics of bacteriocins from human microbiome. Environ Microbiol. 2015;17:2133-43.

253. Lebeer S, Vanderleyden J, De Keersmaecker S. Host interactions of probiotic bacterial surface molecules: comparison with commensals and pathogens. Nat Rev Microbiol. 2010;8:171-84.

254. Shandilya UK, Jadhav S, Panwar V, Kansal V. Probiotics: potent immunomodulatory tool against allergy. Probiotics Antimicro Prot. 2011;3:151-8.

255. von der Weid T, Bulliard C, Schiffrin EJ. Induction by a lactic acid bacterium of a population of CD4 \& T cells with low proliferative capacity that produce transforming growth factor beta and interleukin-10. Clin Diagn Lab Immunol. 2001;8:695-701.

256. Pochard P, Gosset P, Grangette C, Andre C, Tonnel A, Pestel J, et al. Basic and clinical immunology Lactic acid bacteria inhibit T H 2 cytokine production by mononuclear cells from allergic patients. J Allergy Clin Immunol. 2002;1 10:617-23.

257. Christensen HR, Frokiaer H, Pestka JJ. Lactobacilli differentially modulate expression of cytokines and maturation surface markers in murine dendritic cells. J Immunol. 2002;168:171-8.

258. Toh ZQ, Anzela A, Tang MLK, Licciardi PV. Probiotic therapy as a novel approach for allergic disease. Front Pharmacol. 2012;3:1-14.

259. Fujimura KE, Demoor T, Rauch M, Faruqi AA, Jang S, Johnson CC, et al. House dust exposure mediates gut microbiome Lactobacillus enrichment and airway immune defense against allergens and virus infection. Proc Natl Acad Sci U S A. 2014;111:805-10.

260. Kwon H, Lee C, So J, Chae C, Hwang J, Sahoo A, et al. Generation of regulatory dendritic cells and $\mathrm{CD} 4+$ Foxp $3+T$ cells by probiotics administration suppresses immune disorders. Proc Natl Acad Sci U S A. 2010;107:159-64.

261. Jang S, Kim H, Kim Y, Kang M, Kwon J, Seo J, et al. Asthma prevention by Lactobacillus rhamnosus in a mouse model. Allergy Asthma Immunol Res. 2012:4:150-6.

262. Marchetti G, Tincati C, Silvestri G. Microbial translocation in the pathogenesis of HIV infection and AIDS. Clin Microbiol Rev. 2013;26:2-18.

263. Cope EK, Lynch SV. Novel microbiome-based therapeutics for chronic rhinosinusitis. Curr Allergy Asthma Rep. 2015;15:9. https://doi.org/10.1007/ s1 1882-014-0504-y.

264. Spacova I, Petrova MI, Fremau A, Pollaris L, Vanoirbeek J, Seys S, et al. Intranasal administration of probiotic Lactobacillus rhamnosus GG prevents birch pollen induced allergic asthma in a murine model. Allergy. 2019;74:100-10.

265. Wu C, Chen P, Lee Y, Ko J, Lue K. Effects of immunomodulatory supplementation with Lactobacillus rhamnosus on airway inflammation in a mouse asthma model. J Microbiol Immunol Infect. 2016;49:625-35. https:// doi.org/10.1016/j.jmii.2014.08.001

266. Kitz R, Martens U, Zieseniß E, Enck P, Rose MA. Probiotic E. faecalis adjuvant therapy in children with recurrent rhinosinusitis. Cent Eur J Med. 2012;7:7-10.

267. Pellaton C, Nutten S, Thierry A, Boudousqui C, Barbier N, Blanchard C, et al. Intragastric and intranasal administration of Lactobacillus paracasei NCC2461 modulates allergic airway. Int J Inflam. 2012;2012:686739. 
268. Martensson A, Abolhalaj M, Lindstedt M, Martensson A, Olofsson TC, Vasquez AV, et al. Clinical efficacy of a topical lactic acid bacterial microbiome in chronic rhinosinusitis: a randomized controlled trial. Laryngoscope Investig Otolaryngol. 2017;2:410-6.

269. Vasquez A, Forsgren E, Fries I, Paxton RJ, Flaberg E, Szekely L, et al. Symbionts as major modulators of insect health: lactic acid bacteria and honeybees. PLoS One. 2012;7:e33188.

270. Butler É, Oien RF, Lindholm C, Olfonsson TC, Nilson B, Vasquez A. A pilot study investigating lactic acid bacterial symbionts from the honeybee in inhibiting human chronic wound pathogens. Int World J. 2014;13:729-38.

271. Olofsson TC, Vasquez A. Detection and identification of a novel lactic acid bacterial flora within the honey stomach of the honeybee Apis mellifera. Curr Microbiol. 2008;57:356-63.

272. Olofsson TC, Butler Ė, Markowicz P, Lindholm C, Larsson L, Vasquez A. Lactic acid bacterial symbionts in honeybees - an unknown key to honey 's antimicrobial and therapeutic activities. Int World J. 2016;13:668-79.

273. Clarke J, Wu H, Jayasinghe L, Patel A, Reid S, Bayley H. Continuous base identification for single-molecule nanopore DNA sequencing. Nat Nanotechnol. 2009;4:265-70.

274. Eid J, Fehr A, Gray J, Luong K, Lyle J, Otto G, et al. Real-time DNA sequencing from single polymerase molecules. Science. 2009;323:133-8

275. Earl J, Adappa N, Krol J, Bhat A, Balashov S, Ehrlich R, et al. Species-level bacterial community profiling of the healthy sinonasal microbiome using Pacific Biosciences sequencing of full-length 165 rRNA genes. Microbiome. 2018;6:190.

\section{Publisher's Note}

Springer Nature remains neutral with regard to jurisdictional claims in published maps and institutional affiliations. 